\title{
Nuclear Science User Facilities FY 2020 Program Performance Summary
}




\section{DISCLAIMER}

This information was prepared as an account of work sponsored by an agency of the U.S. Government. Neither the U.S. Government nor any agency thereof, nor any of their employees, makes any warranty, expressed or implied, or assumes any legal liability or responsibility for the accuracy, completeness, or usefulness, of any information, apparatus, product, or process disclosed, or represents that its use would not infringe privately owned rights. References herein to any specific commercial product, process, or service by trade name, trade mark, manufacturer, or otherwise, does not necessarily constitute or imply its endorsement, recommendation, or favoring by the U.S. Government or any agency thereof. The views and opinions of authors expressed herein do not necessarily state or reflect those of the U.S. Government or any agency thereof. 


\title{
Nuclear Science User Facilities FY 2020 Program Performance Summary
}

March 2021

\author{
Idaho National Laboratory \\ Nuclear Science User Facilities \\ Idaho Falls, Idaho 83415
}

http://www.inl.gov

\author{
Prepared for the \\ U.S. Department of Energy \\ Office of Nuclear Energy \\ Under DOE Idaho Operations Office \\ Contract DE-AC07-05ID14517
}


Page intentionally left blank 


\section{CONTENTS}

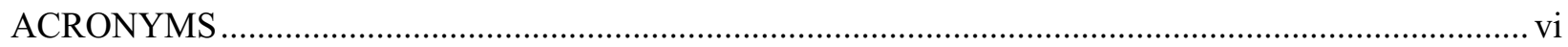

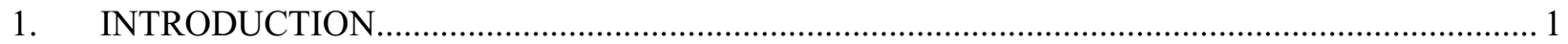

1.1 Background and Performance Evaluation Approach ........................................................... 1

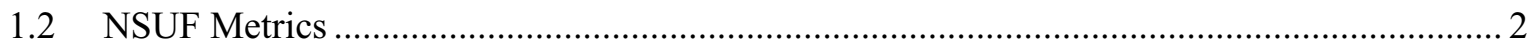

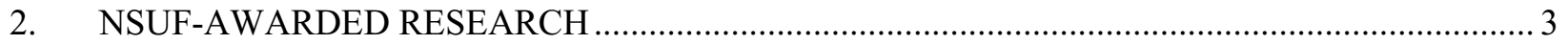

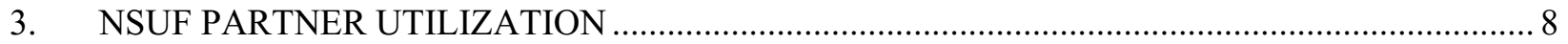

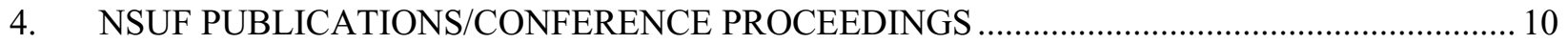

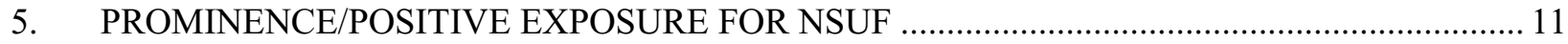

6. NSUF EXPANSION AND DIVERSIFICATION OF NSUF USER COMMUNITY .................... 17

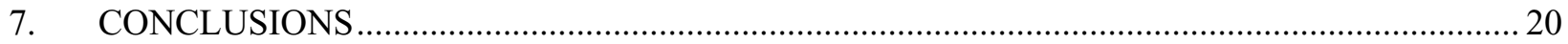

\section{FIGURES}

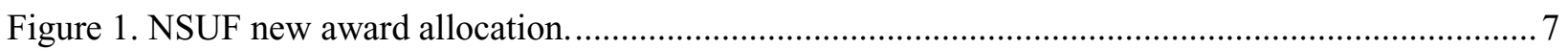

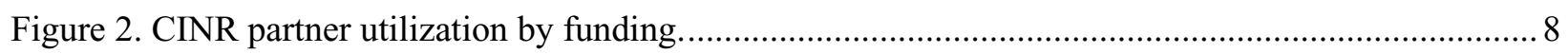

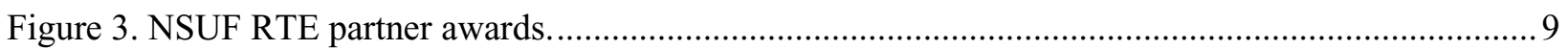

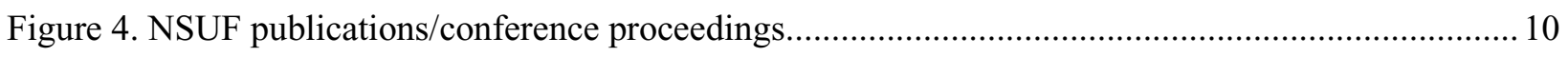

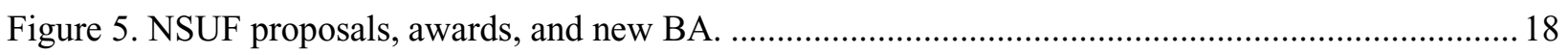

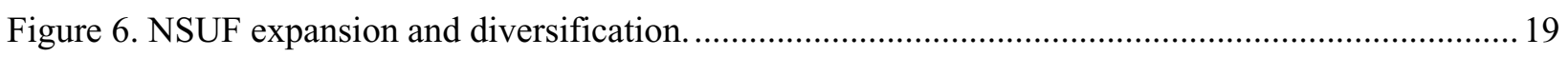

\section{TABLES}

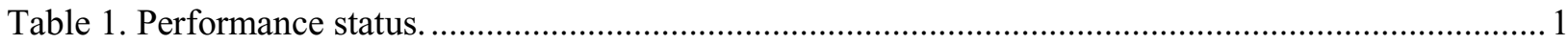

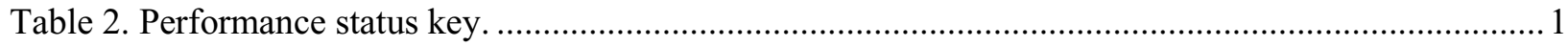

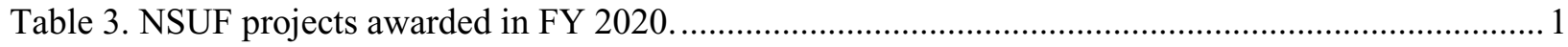

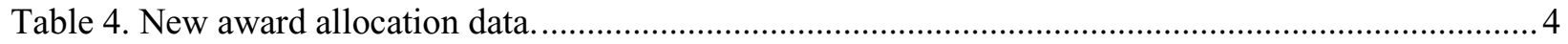

Table 5. CINR funding and partner utilization by funding.................................................................. 9

Table 6. RTE funding and partner utilization by funding...................................................................... 9

Table 7. Data for NSUF publications/conference proceedings............................................................... 10

Table 8. FY 2019 and 2020 invited lectures, plenary lectures, keynote addresses, promotions, awards, PhD dissertations, etc., resulting from NSUF project work or highlighting NSUF opportunities and capabilities.

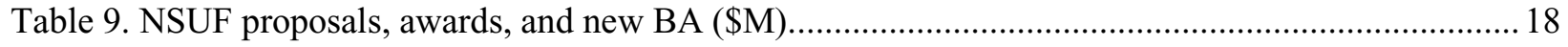

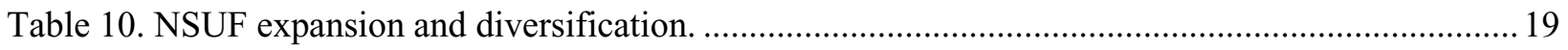


Page intentionally left blank 


\section{ACRONYMS}

A\&M Assembly and Maintenance

ANL Argonne National Laboratory

ANS American Nuclear Society

ATF Accident Tolerant Fuel

BA Budget authority

BNL Brookhaven National Laboratory

BRR Battelle Energy Alliance Research Reactor

CAES Center for Advanced Energy Studies

CINR Consolidated Innovative Nuclear Research

CoMET Combined Materials Experiment Toolkit

DOE Department of Energy

EPRI Electric Power Research Institute

EPSRC Engineering and Physical Sciences Research Council

FaMUS Fuels and Materials Understanding Scale

GAIN Gateway for Accelerated Innovation in Nuclear

GSI General Scientific Infrastructure

INL Idaho National Laboratory

LANL Los Alamos National Laboratory

LLNL Lawrence Livermore National Laboratory

LWR Light-water reactor

MaCS Microscopy and Characterization Suite

MEXT Japanese Ministry of Education, Culture, Sports, Science and Technology

MiNES Materials in Nuclear Energy Systems

MIT Massachusetts Institute of Technology

MRS Materials Research Society

NADM Nuclear Academics' Discussion Meeting

NNUF National Nuclear User Facility

ORNL Oak Ridge National Laboratory

PI Principal Investigator

PICS-NE Program Information Collection System: Nuclear Energy

PNNL Pacific Northwest National Laboratory

PySL Software tool - Least-squares Unfolding with Python

RPV Reactor Pressure Vessel 
SiC Silicon Carbide

SNL Sandia National Laboratories

TEM Transmission Electron Microscope/Microscopy

TMS The Minerals, Metals and Materials Society

TRISO Tri-structural isotropic

US United States

WBS Work Breakdown Structure 


\section{Nuclear Science User Facilities FY 2020 Program Performance Summary}

\section{INTRODUCTION}

Performance status is divided into three classifications: (1) metric exceeded, (2) metric achieved, and (3) metric missed. These are indicated by the colors displayed below:

Table 1. Performance status.

\begin{tabular}{|l|l|c|}
\hline \multicolumn{1}{|c|}{$\begin{array}{c}\text { Performance } \\
\text { Category }\end{array}$} & \multicolumn{1}{|c|}{ Performance Metric } & $\begin{array}{c}\text { Performance } \\
\text { Status }\end{array}$ \\
\hline \multirow{3}{*}{$\begin{array}{l}\text { Program } \\
\text { Performance }\end{array}$} & NSUF-Awarded Research & \\
\cline { 2 - 3 } & Partner Utilization & 0 \\
\cline { 2 - 3 } & Publications/Conference Proceedings & 0 \\
\cline { 2 - 3 } & Prominence/Positive Exposure for NSUF & 0 \\
\cline { 2 - 3 } & NSUF Expand and Diversify User Community & 0 \\
\hline
\end{tabular}

Table 2. Performance status key.

\begin{tabular}{|l|l|}
\hline$\bigcirc$ & Exceeded \\
\hline$\bigcirc$ & Achieved \\
\hline$\bigcirc$ & Missed \\
\hline
\end{tabular}

\subsection{Background and Performance Evaluation Approach}

The Nuclear Science User Facilities (NSUF) first gathered and reported metric data for fiscal year (FY) 2014. The goal of the FY 2014 NSUF Metric Report was to establish metric measures and provide baseline data to evaluate future performance of the NSUF. Metric goals and objectives were each established through NSUF discussions with Department of Energy (DOE) Idaho Operations Office (DOE-ID) and Office of Nuclear Energy (DOE-NE) staff. This report provides the data, analysis, and conclusions for the FY 2020 metrics.

In FY 2020, the NSUF made 64 awards, including 56 Rapid Turnaround Experiments (RTEs) and eight Consolidated Innovative Nuclear Research (CINR) projects. From its inception to the end of FY 2020, the NSUF has awarded 579 projects, shown in Table 3.

Table 3. NSUF projects awarded in FY 2020.

\begin{tabular}{|l|c|}
\hline \multicolumn{1}{|c|}{ Projects } & Number Awarded \\
\hline RTE & 488 \\
\hline Full/CINR & 91 \\
\hline Total Projects & 579 \\
\hline
\end{tabular}


In FY 2020, the NSUF was comprised of Idaho National Laboratory (INL) and capabilities at the following partner institutions:

\section{National laboratories (7)}

- Argonne National Laboratory (ANL)

- Brookhaven National Laboratory (BNL)

- Lawrence Livermore National Laboratory (LLNL)

- Los Alamos National Laboratory (LANL)

- Oak Ridge National Laboratory (ORNL)

- Pacific Northwest National Laboratory (PNNL)

- Sandia National Laboratories (SNL).

\section{Universities (9 plus CAES)}

- Massachusetts Institute of Technology (MIT)

- North Carolina State University

- Purdue University

- Texas A\&M University

- The Ohio State University

- University of California, Berkeley

- University of Florida

- University of Michigan

- University of Wisconsin

- The Center for Advanced Energy Studies (CAES), a research and education consortium among Boise State University, Idaho State University, University of Idaho, and INL.

\section{Industry (1)}

- Westinghouse Churchill Laboratory Services.

\section{International Affiliate (1)}

- Belgian Nuclear Research Centre (SCK-CEN).

\subsection{NSUF Metrics}

The success of the NSUF is currently evaluated by five metrics.

1. NSUF-Awarded Research:

- Metric Objective: Demonstrate efficient use of funding by maximizing funding available for new research awards.

- Performance Metric: Percentage of available annual funding applied to new research awards.

2. Partner Utilization:

- Metric Objective: Effectively utilize NSUF capabilities by providing researchers access to a variety of capabilities.

- Performance Metric: Percentage of new awards (by funding) executed at partner facilities. 
3. Publications/Conference Proceedings:

- Metric Objective: Publicize and document research results through publication in high-impactfactor peer reviewed journals and conference presentations.

- Performance Metric: Number of peer reviewed publications and conference proceedings per year.

4. Prominence/Positive Exposure for the NSUF:

- Metric Objective: Increase the prominence and positive exposure of the NSUF in the research community. This may be a temporary objective until we reach a saturation point, at which point the goal may be to "maintain."

- Performance Metric: Number of invited lectures, plenary lectures, keynote addresses, promotions, awards, PhD dissertations, etc., resulting from NSUF project work or highlighting NSUF opportunities and capabilities.

5. Expansion and Diversification of the NSUF User Community:

- Metric Objective: Expand and diversify the NSUF user community.

- Performance Metric: Number of proposals received and awarded gauged against available funding, project type, number of new PIs, institutions, geographic distribution, and minorityserving institutions.

\section{NSUF-AWARDED RESEARCH}

1. Metric Objective: Demonstrate efficient use of funding by maximizing funding available for new research awards.

2. Performance Metric: Percentage of available annual funding applied to new research awards.

3. Performance Goal: Apply at least $50 \%$ of available annual funding to new research awards, excluding directed activities.

This metric is the ratio of annual funding (new budget authority, not carryover) to the full costs of new awards. For example, $\$ 10 \mathrm{M}$ in new awards with a $\$ 20 \mathrm{M}$ effective budget (full appropriation minus directed activities, such as external contributions) would result in $50 \%$ of annual funding being applied to new awards. This metric ensures an acceptable balance between funding for new research awards and funding for programmatic activities and capability investment.

The data for the analysis is summarized in Table 4. The first two columns are extracted from Program Information Collection System: Nuclear Energy (PICS-NE) and include the Work Breakdown Structure (WBS) number, and a short description of the program area. The third column shows the total allotment for that activity. The fourth column was added to list the items for which the budget is available for awarded research. The fifth column lists the budgets that were allocated for awarded research. Note that for FY 2020, the majority of the \$4M in CINR awards was funded with carry over. The carry-over funds are not included in this metric.

The items that are not included in the Available for New Awards column are discussed below:

1. Management and Integration work package funding is not available for new awards as these activities are directed by DOE.

2. Post-irradiation examination (PIE) Coordination and Irradiation Coordination work packages funding is not available for new awards as the activities in these work packages are necessary to support execution of awards for prior years.

3. High Performance Computing work package funding is not available for new awards as this is a congressionally directed activity. 
4. Nuclear Materials Discovery and Qualification Initiative work package funding is not available for new awards as this is a congressionally directed activity.

5. Nuclear Fuels and Materials Library work package funding is not available for new awards as this is a congressionally directed activity.

6. Cooperative Research work package funding is not available for new awards as the activities in this work package support ongoing industry projects (such as the Electric Power Research Institute [EPRI] and Nuclear Regulatory Commission [NRC] Cooperative Research and Development Agreements [CRADAs]).

7. Capabilities Coordination work package funding is not available for new awards as this is a DOEdirected activity.

8. Office of Technology Transition Awards work package funding is not available for new awards as these activities are directed by DOE.

The items listed below are not included in the Allocated for New Awards column. None of the associated funding is considered an allocation for new awards for the following reasons:

1. Activities within the Program Office control account do not directly support execution of awarded projects.

2. Management Reserve is held for execution of prior awards.

3. Activities within the Combined Materials Experiment Toolkit (CoMET) work package support integration of the NSUF databases (e.g., NEID and NFML), RTE proposal system, and the development of an experiment wizard tool which support the solicitation process.

4. Activities within the Scientific Expertise work package offer INL instrument scientists the opportunity to develop new methodologies and expertise.

5. Activities within the ORNL Infrastructure work package increase research capability.

6. Activities within the Activated Materials Laboratory work package increase research capability at the Advanced Photon Source.

Table 4. New award allocation data.

\begin{tabular}{|c|c|c|c|c|}
\hline WBS & $\begin{array}{c}\text { NEET NSUF Program WBS Element Description } \\
\text { FY } 2020 \text { Year End; \$30,000,000 Initial Budget } \\
\text { Baseline }\end{array}$ & $\begin{array}{l}\text { FY } 2020 \\
\text { Allotments }\end{array}$ & $\begin{array}{l}\text { Available } \\
\text { for New } \\
\text { Awards }\end{array}$ & $\begin{array}{l}\text { Allocated } \\
\text { for New } \\
\text { Awards }\end{array}$ \\
\hline 3.04 & Nuclear Energy Enabling Technology (NEET) NSUF & $30,000,000$ & $9,275,171$ & $1,941,955$ \\
\hline 3.04.01 & Management and Integration & $1,307,249$ & & \\
\hline 3.04.01.01 & DOE-HQ Program Management & $1,127,249$ & & \\
\hline 3.04 .01 .01 & NSUF Program Management Reserves & - & & \\
\hline 3.04 .01 .01 & NSUF Program External Contributions & 19,370 & & \\
\hline 3.04 .01 .01 & NSUF SBIR/STTR External Contributions & $1,095,000$ & & \\
\hline 3.04 .01 .01 & $\begin{array}{l}\text { National Nanotechnology Coordination Office- } \\
\text { DOE-CH }\end{array}$ & 2,000 & & \\
\hline 3.04 .01 .01 & $\begin{array}{l}\text { Program Level HQ Directed Activities (outplant } \\
\text { support)-INL }\end{array}$ & 10,879 & & \\
\hline 3.04.01.02 & Program Controls & 180,000 & & \\
\hline 3.04 .01 .02 & Program Controls-Management of PICS:NE & 180,000 & & \\
\hline 3.04.02 & NSUF Activities & $28,382,751$ & $9,275,171$ & $1,941,955$ \\
\hline 3.04.02.01 & Program Office & 2,943,721 & $2,943,721$ & - \\
\hline
\end{tabular}




\begin{tabular}{|c|c|c|c|c|}
\hline WBS & $\begin{array}{c}\text { NEET NSUF Program WBS Element Description } \\
\text { FY } 2020 \text { Year End; \$30,000,000 Initial Budget } \\
\text { Baseline }\end{array}$ & $\begin{array}{c}\text { FY } 2020 \\
\text { Allotments }\end{array}$ & $\begin{array}{l}\text { Available } \\
\text { for New } \\
\text { Awards }\end{array}$ & $\begin{array}{l}\text { Allocated } \\
\text { for New } \\
\text { Awards }\end{array}$ \\
\hline 3.04 .02 .01 & Program Management & $1,900,000$ & & \\
\hline 3.04 .02 .01 & Outreach, Solicitations, and Technical Oversight & 968,721 & 968,721 & \\
\hline 3.04 .02 .01 & NSUF Users Meeting & 75,000 & 75,000 & \\
\hline 3.04.02.02 & Awarded Research & $4,819,650$ & $2,189,650$ & $1,150,155$ \\
\hline 3.04 .02 .02 & $\begin{array}{l}\text { University and National Laboratory Partner } \\
\text { Subcontracts }\end{array}$ & $1,150,155$ & $1,150,155$ & $1,150,155$ \\
\hline 3.04 .02 .02 & PIE Coordination & 750,000 & & \\
\hline 3.04 .02 .02 & Pre-CINR Pie Projects & - & & \\
\hline 3.04 .02 .02 & Rapid Turnaround Experiments/Beamline & - & - & - \\
\hline 3.04 .02 .02 & Irradiation Coordination & $1,880,000$ & & \\
\hline 3.04 .02 .02 & Pre-CINR Irradiation Projects & - & & \\
\hline 3.04 .02 .02 & Combined Materials Experiment Toolkit (CoMET) & 600,000 & 600,000 & \\
\hline 3.04 .02 .02 & Management Reserves at INL for NSUF Activities & 439,495 & 439,495 & \\
\hline 3.04.02.03 & Cooperative Research & 255,600 & - & - \\
\hline 3.04 .02 .03 & Industry Programs & 255,600 & - & - \\
\hline 3.4.02.04 & Capabilities & $2,350,000$ & $2,350,000$ & - \\
\hline 3.04 .02 .04 & Battelle Energy Alliance Research Reactor (BRR) Cask & - & & \\
\hline 3.04 .02 .04 & $\begin{array}{l}\text { Materials in a Radiation Environment Synchrotron } \\
\text { Facility }\end{array}$ & & & \\
\hline 3.04 .02 .04 & Activated Materials Laboratory & $2,350,000$ & $2,350,000$ & \\
\hline 3.04.02.05 & Infrastructure Management & 305,000 & - & - \\
\hline 3.04 .02 .05 & Capabilities Coordination & 305,000 & & \\
\hline 3.04 .02 .05 & INL Infrastructure Investment & - & - & \\
\hline 3.04 .02 .05 & ORNL Infrastructure Investment (BRR, LAMDA) & - & - & \\
\hline 3.04.02.06 & FY 2015 New Awards & - & - & - \\
\hline 3.04 .02 .06 & Boise 15-8242 PIE & - & & \\
\hline 3.04.02.07 & FY 2016 New Awards & - & - & - \\
\hline 3.04 .02 .07 & Michigan ZJ 16-10200 PIE (LAMDA) & - & & \\
\hline 3.04 .02 .07 & CSM JK 16-10584 PIE (MFC/CAES) & - & & \\
\hline 3.04 .02 .07 & ORNL TG 16-10764 PIE (LAMDA) & - & & \\
\hline 3.04 .02 .07 & Idaho State HW 16-10537 PIE (MFC/CAES) & - & & \\
\hline 3.04 .02 .07 & GE Hitachi MC 16-10393 PIE (MFC/CAES) & - & & \\
\hline 3.04 .02 .07 & Michigan JZ 16-10200 Ion Irradiation (MIBL) & - & & \\
\hline 3.04 .02 .07 & Michigan FG 16-10432 Implantation/Irradiation (MIBL) & - & & \\
\hline 3.04.02.08 & Scientific Expertise & $1,000,000$ & $\mathbf{1 , 0 0 0 , 0 0 0}$ & \\
\hline 3.04 .02 .08 & Scientific Expertise at INL & $1,000,000$ & $1,000,000$ & \\
\hline 3.04.02.09 & New Initiatives & - & - & - \\
\hline 3.04 .02 .09 & International Collaborations - INL & - & - & - \\
\hline 3.04.02.10 & FY 2017 New Awards & - & - & - \\
\hline 3.04 .02 .10 & Penn State MT 17-12797 Irradiation (IVEM) & - & - & - \\
\hline 3.04 .02 .10 & ORNL LT 17-13050 ORNL (LAMDA) & - & - & - \\
\hline 3.04 .02 .10 & Boise YZ 17-12527 Irradiation (NCSUR, MITR) & - & - & - \\
\hline 3.04 .02 .10 & Pittsburgh KC 17-13073 Irradiation (MITR) & - & - & - \\
\hline 3.04 .02 .10 & Pittsburgh KC 17-13073 PIE (MCOE) & - & - & - \\
\hline 3.04 .02 .10 & Gen Atomics CD 17-12573 Irradiation (HFIR) & - & - & - \\
\hline 3.04 .02 .10 & Gen Atomics CD 17-12573 PIE (LAMDA) & - & - & - \\
\hline 3.04 .02 .10 & AREVA JS 17-13007 Irradiation (HFIR) & - & - & - \\
\hline 3.04 .02 .10 & AREVA JS 17-13007 PIE (IMET) & - & - & - \\
\hline 3.04 .02 .10 & EPRI KY 17-12985 (HFEF) & - & - & - \\
\hline 3.04 .02 .10 & INL 17-12976 (HFEF) & - & - & - \\
\hline 3.04 .02 .10 & Westinghouse PX 17-13106 PIE (MCOE) & - & - & \\
\hline
\end{tabular}




\begin{tabular}{|c|c|c|c|c|}
\hline WBS & $\begin{array}{l}\text { NEET NSUF Program WBS Element Description } \\
\text { FY } 2020 \text { Year End; \$30,000,000 Initial Budget } \\
\text { Baseline }\end{array}$ & $\begin{array}{c}\text { FY } 2020 \\
\text { Allotments }\end{array}$ & $\begin{array}{l}\text { Available } \\
\text { for New } \\
\text { Awards }\end{array}$ & $\begin{array}{l}\text { Allocated } \\
\text { for New } \\
\text { Awards }\end{array}$ \\
\hline 3.04 .02 .10 & University of Illinois JS 17-13211 PIE (HFEF) & - & - & - \\
\hline 3.04 .02 .10 & EPRI AK 17-13088 PIE (PNNL) & - & - & - \\
\hline 3.04 .02 .10 & LANL TL 17-13004 Irradiation (UW/MIBL) & - & - & - \\
\hline 3.04 .02 .10 & EPRI KY 17-12985 Irradiation (ATR) & - & - & - \\
\hline 3.04 .02 .10 & EPRI KY 17-12985 Irrad (ORNL-IFEL) & - & - & - \\
\hline 3.04.02.11 & FY 2018 New Awards & - & - & - \\
\hline 3.04 .02 .11 & Texas A\&M SM 18-14741 (ATR) & - & - & - \\
\hline 3.04 .02 .11 & Texas A\&M SM 18-14741 (HFEF) & - & - & - \\
\hline 3.04 .02 .11 & Notre Dame YZ 18-14730 (MITR, MIBL) & - & - & - \\
\hline 3.04 .02 .11 & Ohio State MK 18-14749 (OSURR, WIBL) & - & - & - \\
\hline 3.04 .02 .11 & Aeroprobe CC 18-14788 PIE (HFEF) & - & - & - \\
\hline 3.04 .02 .11 & Florida AA 18-14704 PIE (HFEF) & - & - & - \\
\hline 3.04 .02 .11 & ORNL KF 18-14717 PIE (LAMDA) & - & - & - \\
\hline 3.04 .02 .11 & ORNL KF 18-14717 Irradiation (MIBL) & - & - & - \\
\hline 3.04 .02 .11 & INL CS 18-14772 PIE (HFEF/Westinghouse) & - & - & - \\
\hline 3.04 .02 .11 & MIT JL 18-14783 Irradiation (HFIR) & - & - & - \\
\hline 3.04 .02 .11 & MIT JL 18-14783 PIE (LAMDA) & - & - & - \\
\hline 3.04 .02 .11 & MIT JL 18-14783 PIE (HFEF) & - & - & - \\
\hline 3.04.02.12 & FY 2019 New Awards & - & - & - \\
\hline 3.04 .02 .12 & Kairos RL 19-17159 Irradiation (HFIR) & - & - & - \\
\hline 3.04 .02 .12 & Kairos RL 19-17159 PIE (IFEL) & & & \\
\hline 3.04 .02 .12 & Pittsburgh HB 19-16549 (TREAT) & & & \\
\hline 3.04 .02 .12 & Pittsburgh HB 19-16549 (MFC) & & & \\
\hline 3.04 .02 .12 & Ohio State JZ 19-16583 (TREAT) & & & \\
\hline 3.04 .02 .12 & Ohio State JZ 19-16583 (MFC) & & & \\
\hline 3.04 .02 .12 & INL JD 19-16380 (MITR/OSU) & & & \\
\hline 3.04 .02 .12 & Mich IJ 19-16895 (OSURR) & & & \\
\hline 3.04 .02 .12 & Purdue JW 19-16297 (ATR) & & & \\
\hline 3.04 .02 .12 & Purdue JW 19-16297 (MFC/Westinghouse) & & & \\
\hline 3.04 .02 .12 & Nuscale HX 19-16547 (ATR) & & & \\
\hline 3.04 .02 .12 & Nuscale HX 19-16547 (MFC/Westinghouse) & & & \\
\hline 3.04 .02 .12 & Westinghouse MI 19-16567 (Mich/Westinghouse) & & & \\
\hline 3.04 .02 .12 & Westinghouse JC 19-17109 (HFIR) & & & \\
\hline 3.04 .02 .12 & Westinghouse JC 19-17109 (PIE) & & & \\
\hline 3.04.02.13 & Nuclear Fuels and Materials Library (NFML) & $2,984,429-$ & - & - \\
\hline 3.04 .02 .13 & Nuclear Fuels and Materials Library (NFML) & $2,263,774$ & - & - \\
\hline 3.04 .02 .13 & SAM-2 & 720,655 & - & - \\
\hline 3.04.02.14 & High Performance Computing & $9,948,122$ & - & - \\
\hline 3.04 .02 .14 & High Performance Computing & $5,327,197$ & - & - \\
\hline 3.04 .02 .14 & HPC Hardware/Software Maintenance/Licenses & 894,112 & - & - \\
\hline 3.04 .02 .14 & HPC Sawtooth Lease & $3,726,813$ & - & - \\
\hline 3.04.02.15 & NMDQi & $2,984,429$ & - & - \\
\hline 3.04 .02 .15 & NMDQi Management & $2,584,429$ & - & - \\
\hline 3.04 .02 .15 & NMDQi FY 2020 CINR Award Reserve-DOE-ID & 400,000 & - & \\
\hline 3.04.02.16 & FY 2020 New Awards* & 791,800 & 791,800 & 791,800 \\
\hline 3.04 .02 .16 .04 & FY 2020 New Awards-ANL & 175,000 & 175,000 & 175,000 \\
\hline $3.04 .02 .16 . \mathrm{xx}$ & FY 2020 New Awards-INL & & - & \\
\hline 3.04 .02 .16 .03 & FY 2020 New Awards-ORNL & 433,000 & 433,000 & 433,000 \\
\hline 3.04 .02 .16 .01 & FY 2020 New Awards-PNNL & 162,000 & 162,000 & 162,000 \\
\hline 3.04 .02 .16 .02 & FY 2020 New Awards-SNL & 21,800 & 21,800 & 21,800 \\
\hline
\end{tabular}




\begin{tabular}{|c|c|c|c|c|}
\hline WBS & $\begin{array}{c}\text { NEET NSUF Program WBS Element Description } \\
\text { FY } 2020 \text { Year End; \$30,000,000 Initial Budget } \\
\text { Baseline }\end{array}$ & $\begin{array}{c}\text { FY } 2020 \\
\text { Allotments }\end{array}$ & $\begin{array}{l}\text { Available } \\
\text { for New } \\
\text { Awards }\end{array}$ & $\begin{array}{l}\text { Allocated } \\
\text { for New } \\
\text { Awards }\end{array}$ \\
\hline 3.04.04 & Office of Technology Transition Awards-DOE-HQ & 310,000 & - & - \\
\hline 3.04.04.01 & Office of Technology Transition Awards-DOE-HQ & 310,000 & - & - \\
\hline 3.04 .04 .01 & Office of Technology Transition Awards-DOE-HQ & 310,000 & - & - \\
\hline 3.04 .04 .01 & Office of Technology Transition Awards-INL & - & - & - \\
\hline 3.04 .04 .01 & Office of Technology Transition Awards-LLNL & - & - & - \\
\hline 3.04 .04 .01 & Office of Technology Transition Awards-ANL & - & - & - \\
\hline 3.04.05 & GAIN Management & - & - & - \\
\hline 3.04.05.01 & GAIN Management & - & - & - \\
\hline 3.04 .05 .01 & NSUF Contributions to GAIN-ANL & - & - & - \\
\hline 3.04 .05 .01 & NSUF Contributions to GAIN (Third Way)-DOE-ID & & & \\
\hline 3.04 .05 .01 & NSUF Contributions to GAIN-ANL & & & \\
\hline 3.04 .05 .01 & NSUF Contributions to GAIN-ANL & & & \\
\hline 3.04 .05 .01 & NSUF Contributions to GAIN-ANL & & & \\
\hline
\end{tabular}

* New award funding for non-national laboratory partners flows through INL. For FY2020, all CINR awards at INL, university, and industry partners were funded with carryover dollars.

For FY 2020, \$9,275,171 were available for new awards and \$1,941,955 were allocated for new awards. This means $21 \%$ of available annual funding was applied to new research awards. The data are presented graphically in Figure 1.

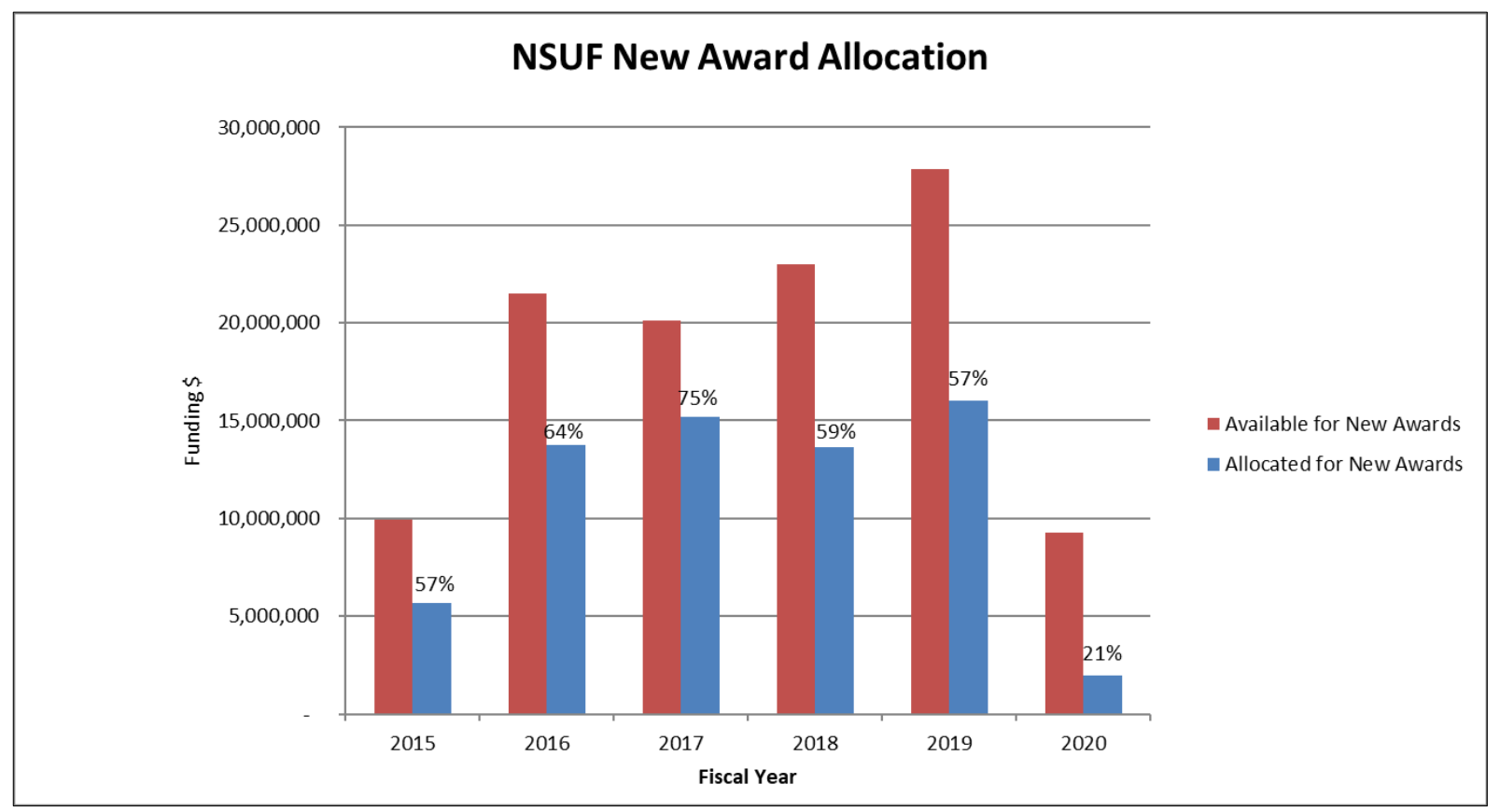

Figure 1. NSUF new award allocation.

The percentage of available annual funding applied to new research awards decreased significantly from FY 2019 to FY 2020. The dollar amount of new budget authority (BA) funding allocated to new awards decreased by more than \$14M. The root cause for this precipitous drop is the FY 2020 
appropriation level and earmarks for the NSUF. The \$30M appropriation level, down from \$44M in FY 2019, strangled with \$16M in earmarks severely impacted the NSUF's new award budget.

\section{Conclusions:}

The goal of $50 \%$ for new award allocation was not met.

It is anticipated that the NSUF will fail to meet this metric in FY 2021 as the appropriation level and language is very similar to FY 2020 . With budget earmarks of $\$ 15 \mathrm{M}$ or more, a budget of at least $\$ 50 \mathrm{M}$ is needed in order for NSUF to perform at the levels of success achieved in FY 2016 through FY 2019.

\section{NSUF PARTNER UTILIZATION}

1. Metric Objective: Effectively utilize NSUF capabilities by providing researchers access to a variety of capabilities.

2. Performance Metric: Percentage of new awards (by funding) executed at partner facilities.

3. Performance Goal: $20 \%$ subject to change based on final award ranking and preferred capability for awarded scope of work.

FY 2020 partner utilization data are taken directly from the FY 2020 final award budgets.

Figure 2 and Figure 2. CINR partner utilization by funding.

Table 5 present CINR partner facility utilization from the perspective of the total estimated cost of awarded CINR proposals and the estimated cost awarded to NSUF partners, excluding CAES Microscopy and Characterization Suite (MaCS). CAES MaCS CINR partner costs have been excluded from the total because specific award amounts are not associated with CAES MaCS access. CAES MaCS is funded on an annual basis, not on a set project basis; this funding covers both CINR and RTE support.

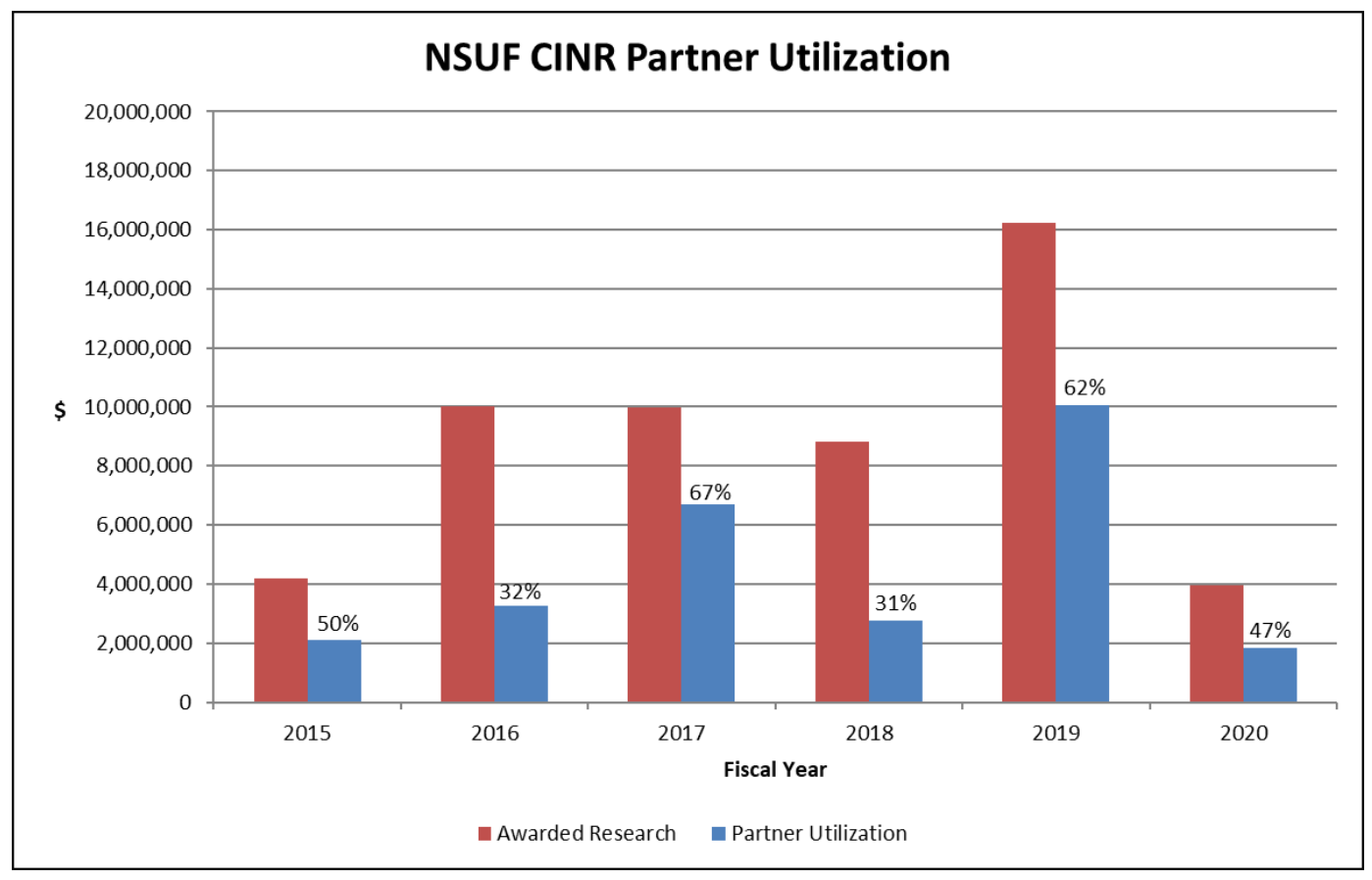

Figure 2. CINR partner utilization by funding. 
Table 5. CINR funding and partner utilization by funding.

\begin{tabular}{|l|r|r|r|r|r|r|c|}
\hline & FY 2015 & \multicolumn{1}{|c|}{ FY 2016 } & FY 2017 & \multicolumn{1}{c|}{ FY 2018 } & FY 2019 & FY 2020 & Total \\
\hline $\begin{array}{l}\text { Partner } \\
\text { Utilization }\end{array}$ & $\$ 2,101,116$ & $\$ 3,248,208$ & $\$ 6,713,248$ & $\$ 2,754,504$ & $\$ 10,047,222$ & $\$ 1,854,839$ & $\$ 26,719,037$ \\
\hline $\begin{array}{l}\text { Awarded } \\
\text { Research }\end{array}$ & $\$ 4,201,907$ & $\$ 10,000,000$ & $\$ 9,973,909$ & $\$ 8,837,886$ & $\$ 16,216,249$ & $\$ 3,973,366$ & $\$ 53,203,317$ \\
\hline $\begin{array}{l}\text { \% Partner } \\
\text { Utilization }\end{array}$ & $50 \%$ & $32 \%$ & $67 \%$ & $31 \%$ & $62 \%$ & $47 \%$ & $50 \%$ \\
\hline
\end{tabular}

Figure 3 and Table 6 present RTE partner facility utilization from the perspective of award value. Beginning in FY 2017, cost estimates were obtained for all RTE proposals. This allows for a better representation of partner utilization than was possible for previous metrics reports that utilized RTE award numbers. RTE awards that utilize multiple facilities are now accounted for properly. The award values include the costs of CAES utilization.

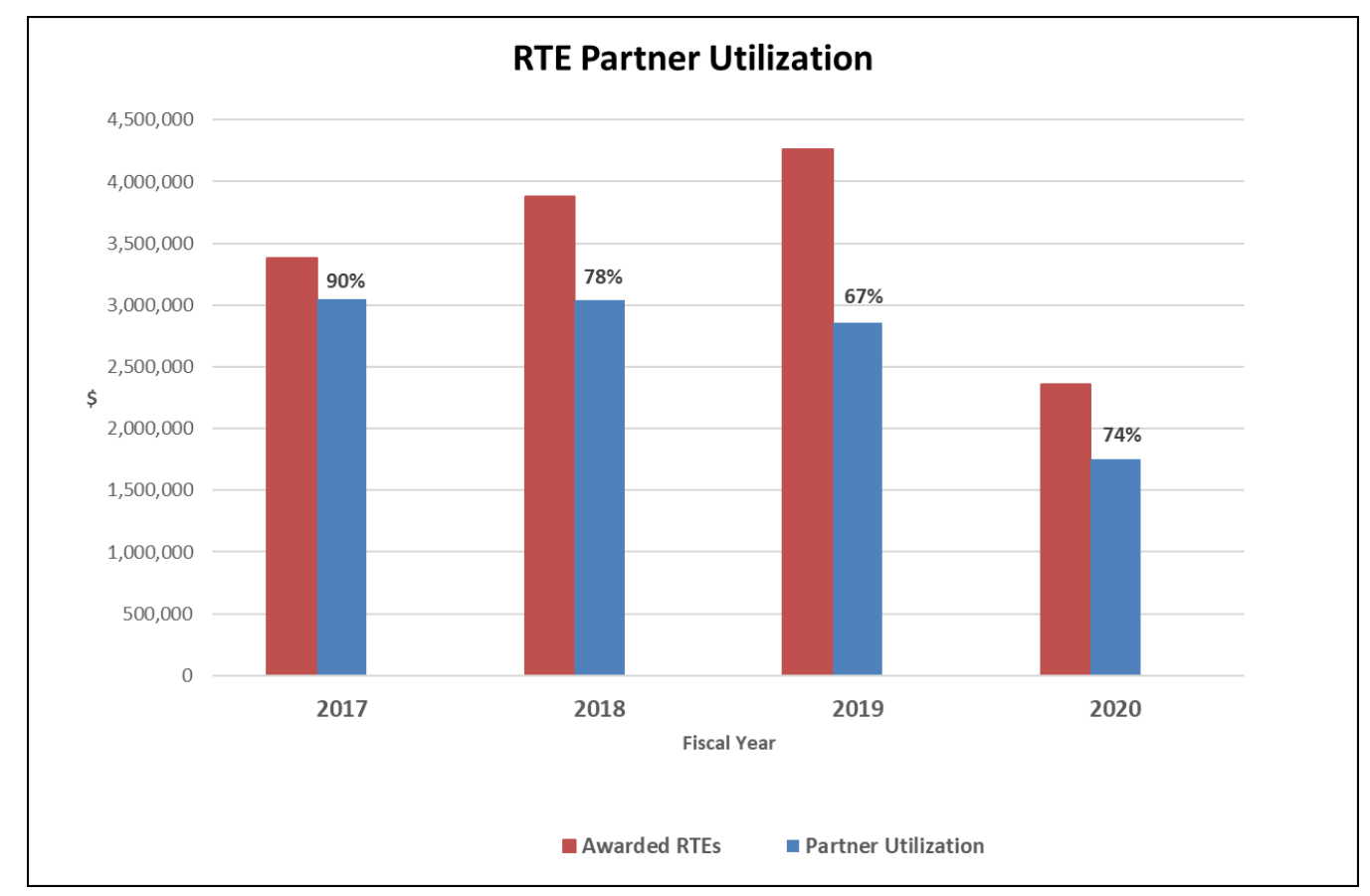

Figure 3. NSUF RTE partner awards.

Table 6. RTE funding and partner utilization by funding.

\begin{tabular}{|l|r|r|r|r|r|}
\hline & \multicolumn{1}{|c|}{ FY 2017 } & \multicolumn{1}{c|}{ FY 2018 } & \multicolumn{1}{c|}{ FY 2019 } & \multicolumn{1}{c|}{ FY 2020 } & \multicolumn{1}{c|}{ Total } \\
\hline Partner Utilization & $\$ 3,048,213$ & $\$ 3,038,020$ & $\$ 2,856,268$ & $\$ 1,751,504$ & $\$ 14,094,005$ \\
\hline Awarded Research & $\$ 3,380,357$ & $\$ 3,881,870$ & $\$ 4,260,918$ & $\$ 2,361,957$ & $\$ 17,335,102$ \\
\hline \% Partner Utilization & $90 \%$ & $78 \%$ & $67 \%$ & $74 \%$ & $81 \%$ \\
\hline
\end{tabular}

In FY 2020, eight CINR projects were awarded with seven of those awards utilizing partner facilities.

\section{Conclusions:}

The percentage of CINR awards being executed at partner facilities continues to exceed the goal.

The percentage of RTE awards being executed at partner facilities continues to exceed the goal. 
The NSUF is effectively utilizing its partner capabilities. INL is the lead and primary laboratory of the NSUF. An appropriate balance in the utilization of INL and partner facilities needs to be maintained during the selection process.

\section{NSUF PUBLICATIONS/CONFERENCE PROCEEDINGS}

1. Metric Objective: Publicize and document research results through publication in high impact factor peer reviewed journals and conference proceedings.

2. Performance Metric: Number of peer reviewed publications and conference proceedings per year.

3. Performance Goal: Minimum of 20 journal publications or conference proceedings per year.

The NSUF publications and conference proceedings are reported by calendar year. Figure 4 and Table 7 show the number of NSUF-supported peer review publications and conference proceedings for 2015 to 2020 as known at the time of preparation of this metrics report.

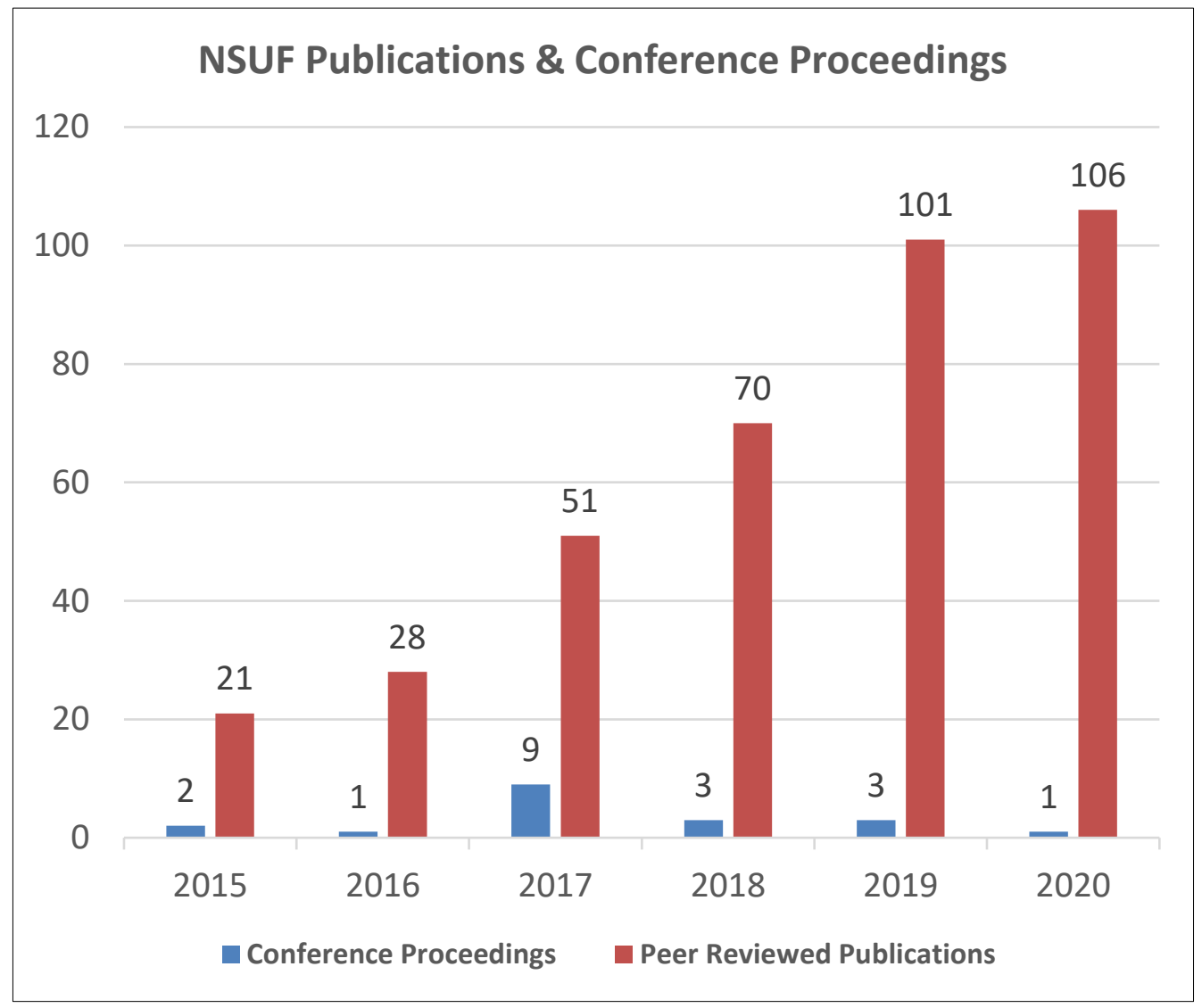

Figure 4. NSUF publications/conference proceedings.

Table 7. Data for NSUF publications/conference proceedings.

\begin{tabular}{|l|r|r|r|r|r|r|}
\hline & \multicolumn{1}{|c|}{ CY 2015 } & \multicolumn{1}{c|}{ CY 2016 } & CY 2017 & CY 2018 & CY 2019 & CY 2020 \\
\hline Conference Proceedings & 2 & 1 & 9 & 3 & 3 & 1 \\
\hline Peer Reviewed Publications & 21 & 28 & 51 & 70 & 101 & 106 \\
\hline Citations & 157 & 189 & 310 & 548 & 866 & 1,220 \\
\hline
\end{tabular}

Historically, the NSUF gathered the data for this metric from principal investigators (PIs) as works cited during the proposal application processes and through web searches. To provide a more rigorous 
count for the metric, the numbers of peer reviewed publications and conference proceedings are now taken from the Clarivate Analytics "Web of Science" database utilizing a search for all outputs acknowledging NSUF support. The number of peer-reviewed publications per calendar year show continuous growth from 21 in 2015 to 106 in 2020. While the actual numbers in the figure and table differ somewhat from those self-reported by the NSUF PIs, the underlying growth is the same. Discrepancies arise from PIs reporting work as supported by the NSUF, but not providing an acknowledgement in the publication.

\section{Conclusions:}

For FY 2020, the 106 journal publications alone significantly exceeded the goal of 20 journal publications or conference proceedings. The number of conference proceedings papers represents only a small fraction of the total peer reviewed outputs, with the maximum counted being nine in 2017 . The number dropped to one in 2020. The most probable reason for this decrease is the effect of the COVID-19 pandemic on the number of scientific gatherings.

Also included in Table 7 is the number of citations of NSUF supported research. This number quantifies the impact of the NSUF supported research portfolio, and has grown significantly from 157 in 2015 to 1,220 in 2020, and may be a suitable metric for judging future performance.

The NSUF continues to produce impactful results as can be observed in the increasing number of peer-reviewed publications. The Journal of Nuclear Materials is by far the most popular journal in which the NSUF research is published. It is the most important journal for not only the NSUF but the broader nuclear fuels and materials research community.

\section{PROMINENCE/POSITIVE EXPOSURE FOR NSUF}

1. Metric Objective: Increase the prominence and positive exposure of the NSUF in the research community. This may be a temporary objective until we reach a saturation point, at which point the goal may be to "maintain."

2. Performance Metric: Number of invited lectures, plenary lectures, keynote addresses, promotions, awards, PhD dissertations, etc., resulting from NSUF project work or highlighting NSUF opportunities and capabilities.

3. Performance Goal: 5\% increase over previous yearly average.

FY 2020 data for this measure were gathered directly from required quarterly reports and emails from PIs. Table 8 provides information on the FY 2019 and FY 2020 performance.

Table 8. FY 2019 and 2020 invited lectures, plenary lectures, keynote addresses, promotions, awards, $\mathrm{PhD}$ dissertations, etc., resulting from NSUF project work or highlighting NSUF opportunities and capabilities.

\begin{tabular}{|l|l|l|}
\hline \multicolumn{3}{|c|}{ Prominence/Positive Exposure for NSUF } \\
\hline \multicolumn{3}{|c|}{ FY 2020 } \\
\hline 1. & $\begin{array}{l}\text { J. R. Kennedy was elected as a Fellow of the American Nuclear Society (ANS), September } \\
\text { 2020. }\end{array}$ & J. R. Kennedy \\
\hline 2. & E. Marquis was elected a Fellow of the International Field Emission Society, 2020. & E. Marquis \\
\hline 3. & $\begin{array}{l}\text { Mishima Award to Yutai Katoh for being a leading architect of today's nuclear grade } \\
\text { ceramic composites, elevating them from laboratory curiosity to engineering materials of } \\
\text { importance through the application of fundamental materials science, ANS Winter } \\
\text { Meeting, November 2019. }\end{array}$ & Y. Katoh \\
\hline 4. & $\begin{array}{l}\text { Mark Mills Award to Caleb Massey: For his work entitled: “Multiscale investigations of } \\
\text { nanoprecipitate nucleation, growth, and coarsening in annealed low-Cr oxide dispersion } \\
\text { strengthened FeCrAl powder," ANS Winter Meeting, November 2019. }\end{array}$ & C. Massey \\
\hline
\end{tabular}




\begin{tabular}{|c|c|c|}
\hline 5. & $\begin{array}{l}\text { Award: J. Boyington and M. Reichenberger receive } 2020 \text { Exceptional Innovation } \\
\text { Contribution Award for the development of PySL (technology helps streamline and } \\
\text { augment processes related to dosimetry measurement across NSUF partner facilities), Idaho } \\
\text { National Laboratory's Technology Deployment Office. }\end{array}$ & $\begin{array}{l}\text { J. Boyington, M. } \\
\text { Reichenberger }\end{array}$ \\
\hline 6. & $\begin{array}{l}\text { B. Heidrich was promoted to Department Manager for Post-Irradiation Examination and } \\
\text { Project Execution, Idaho National Laboratory. }\end{array}$ & B. Heidrich \\
\hline 7. & $\begin{array}{l}\text { Elected: Executive Committee, Materials Science and Technology Division, Materials } \\
\text { Research Society, June } 2020 .\end{array}$ & S. M. Pimblott \\
\hline 8. & $\begin{array}{l}\text { PhD dissertation: "Engineering single-atom dynamics with electron irradiation," MIT } \\
\text { department of Nuclear Science and Engineering. Thesis won the department's annual Del } \\
\text { Favero PhD thesis prize. }\end{array}$ & C. Su (PhD Student) \\
\hline 9. & $\begin{array}{l}\text { PhD dissertation: Included work performed on the Alemnis system on } \mathrm{Mg}-\mathrm{Nb} \text { multilayered } \\
\text { nanolaminates, University of Nevada-Reno, Fall } 2019 .\end{array}$ & M. Jain (PhD Student) \\
\hline 10. & $\begin{array}{l}\text { PhD dissertation: "Development and characterization of nanostructured steels and high- } \\
\text { entropy alloys for nuclear application," Nuclear Engineering, Missouri University of } \\
\text { Science and Technology, December } 2019 \text {. }\end{array}$ & $\begin{array}{l}\text { A. Hoffman ( } \mathrm{PhD} \\
\text { Student) }\end{array}$ \\
\hline 11. & $\begin{array}{l}\text { PhD dissertation: "The Role of Damage Rate on Cavity Nucleation with Co-Injected } \\
\text { Helium in Dual Ion Irradiated T91 Steel,” Department of Nuclear Engineering \& } \\
\text { Radiological Sciences, University of Michigan, January } 2020 \text {. }\end{array}$ & S. Taller (PhD Student) \\
\hline 12. & $\begin{array}{l}\text { PhD dissertation: “Analysis of Heavy Ion Radiation Damage in Titanium and Titanium } \\
\text { Alloys," Department of Chemical Engineering and Materials Science, Michigan State } \\
\text { University, March } 2020 .\end{array}$ & $\begin{array}{l}\text { A. Amroussia }(\mathrm{PhD} \\
\text { Student) }\end{array}$ \\
\hline 13. & $\begin{array}{l}\text { PhD. dissertation: "Material Study and Additive Technology Development of Chalcogenide } \\
\text { Glass for Hybrid Plasmonic Temperature Sensor," Department of Electrical and Computer } \\
\text { Engineering, Boise State University, April 2020. }\end{array}$ & $\begin{array}{l}\text { A-A. Ahmed Simon } \\
\text { (PhD Student) }\end{array}$ \\
\hline 14. & $\begin{array}{l}\text { PhD dissertation: "Characterization and Modeling of Irradiation Induced Nanoclusters in } \\
\text { Ferritic-Martensitic and Zirconium-Niobium Alloys," Materials Science and Engineering, } \\
\text { University of Idaho, July } 2020 .\end{array}$ & S. Asisa (PhD Student) \\
\hline 15. & $\begin{array}{l}\text { PhD dissertation: "Irradiation Induced Redistribution of Alloying Elements in } \mathrm{Zr}-\mathrm{Nb} \\
\text { Alloys and Its Effect on Corrosion Kinetics," Materials Science and Engineering } \\
\text { Department, University of Wisconsin-Madison, August } 2020 \text {. }\end{array}$ & Z. Yu (PhD Student) \\
\hline 16. & $\begin{array}{l}\text { Member: Organizing and Technical Program Committees, Materials in Nuclear Energy } \\
\text { Systems Conference October } 2019 .\end{array}$ & S. M. Pimblott \\
\hline 17. & $\begin{array}{l}\text { Symposium Co-Organizer and Session Chair: Advanced Characterization of Nuclear Fuels } \\
\text { and Materials, Microscopy \& Microanalysis } 2020 \text {, August } 2020 .\end{array}$ & S. M. Pimblott \\
\hline 18. & Invited talk: “Atomic Engineering,” MIT Materials Day Symposium, October 9, 2019. & J. Li \\
\hline 19. & $\begin{array}{l}\text { Invited talk: "Advanced Characterization of } \mathrm{UO}_{2} \text { and } \mathrm{ThO}_{2}, " \mathrm{AVS} 66^{\text {th }} \text { International, } \\
\text { Columbus, October } 2019 .\end{array}$ & L. He \\
\hline 20. & $\begin{array}{l}\text { Invited lecture: “Advanced Characterization of Nuclear Materials: Capabilities and } \\
\text { Examples,” Department of Mechanical and Aerospace Engineering Seminar, The Ohio } \\
\text { State University, October } 2019 .\end{array}$ & L. He \\
\hline 21. & $\begin{array}{l}\text { Invited talk: "Helium irradiation induced ultra-high strength nanotwinned } \mathrm{Cu} \text { with } \\
\text { nanovoids," } 56^{\text {th }} \text { Annual Technical meeting of the Society of Engineering Sciences } \\
\text { (SES2019), St. Louis, October } 2019 .\end{array}$ & X. Zhang \\
\hline 22. & $\begin{array}{l}\text { Invited talk: "A new method for TEM in situ tensile testing of ion irradiated alloys," } \\
\text { Materials in Nuclear Energy Systems, Baltimore, October } 2019 .\end{array}$ & $\begin{array}{l}\text { P. Warren, G. Warren, C. } \\
\text { Enebechi, J. Burns, M. } \\
\text { Dubey, and J. Wharry }\end{array}$ \\
\hline 23. & $\begin{array}{l}\text { Invited Talk: "Mechanical properties \& dislocation dynamics in irradiated FeCrAl using in } \\
\text { situ TEM tensile tests," Materials in Nuclear Energy Systems, Baltimore, October } 2019 .\end{array}$ & $\begin{array}{l}\text { G. Warren, Y. Pachaury, } \\
\text { C. Enebechi, J. Burns, } \\
\text { M. Dubey, Y. Wu, A. El- } \\
\text { Azab, J. Wharry }\end{array}$ \\
\hline 24. & $\begin{array}{l}\text { Invited lecture: "Microstructural characterization of metallic fuel alloys," Materials in } \\
\text { Nuclear Energy Systems (MiNES) topical conference, Baltimore, MD, October 6-10, } 2019 .\end{array}$ & A. Aitkaliyeva \\
\hline 25. & $\begin{array}{l}\text { Invited talk: "High-Entropy Carbide Ceramics for Extreme Environments," Materials } \\
\text { Science \& Technology 2019, Portland, Oregon, October } 2019 .\end{array}$ & B. Cui \\
\hline
\end{tabular}




\begin{tabular}{|c|c|c|}
\hline 26. & $\begin{array}{l}\text { Invited talk: "In situ irradiation and heating of synthetic SiC and implications for the } \\
\text { origins of C-rich circumstellar and interstellar materials," } 2019 \text { Presolar Grain Workshop, } \\
\text { University of Chicago, Chicago, IL, October } 2019 .\end{array}$ & $\begin{array}{l}\text { T.J. Zega, J. Bernal, J.Y. } \\
\text { Howe, P. Haenecour, S. } \\
\text { Amari, L.M. Ziurys }\end{array}$ \\
\hline 27. & $\begin{array}{l}\text { Invited talk: "Winning Collaborative Research Hubs," CAES Expert Panel, CAES, Idaho } \\
\text { Falls, November } 2019 .\end{array}$ & S. M. Pimblott \\
\hline 28. & $\begin{array}{l}\text { Invited talk: “Advanced Test Reactor I-Loop Irradiation Facility and Flux Booster Element } \\
\text { Keith Means (MPR)," ANS Winter Meeting, November } 2019 .\end{array}$ & $\begin{array}{l}\text { K. Means, T. Maddock, } \\
\text { N. Woolstenhulme, N. } \\
\text { Oldham, K. Horman }\end{array}$ \\
\hline 29. & $\begin{array}{l}\text { Invited talk: "Neutron Radiography and Radiation Effects Testing Using a High-Flux } \\
\text { Electrically Driven Neutron Generator," ANS Winter Meeting, November } 2019 .\end{array}$ & $\begin{array}{l}\text { R. Radel, M. Taylor, C. } \\
\text { Seyfert, J. McCumber, L. } \\
\text { Jacobson, } \\
\text { E. Sengbusch }\end{array}$ \\
\hline 30. & $\begin{array}{l}\text { Invited talk: "Progress in Critically Assessing the NSUF Research Portfolio," ANS Winter } \\
\text { Meeting, November } 2019 .\end{array}$ & $\begin{array}{l}\text { S. M. Pimblott, J. R. } \\
\text { Kennedy }\end{array}$ \\
\hline 31. & $\begin{array}{l}\text { Invited talk: "Assessment of Additively-Manufactured Zircaloy-2 for LWR Applications," } \\
\text { ANS Winter Meeting, November } 2019 .\end{array}$ & $\begin{array}{l}\text { J. M. Partezana, W. T. } \\
\text { Cleary, P. Xu }\end{array}$ \\
\hline 32. & $\begin{array}{l}\text { Invited talk: "High Power Irradiation Testing of TRISO Particles in Miniature Fuel } \\
\text { Specimens in HFIR," ANS Winter Meeting, November } 2019 .\end{array}$ & $\begin{array}{l}\text { R. Latta, B. Collin, M. } \\
\text { Hackett, N. Brown, J. } \\
\text { Hunn, C. Petrie, T. } \\
\text { Gerczak, G. Helmreich }\end{array}$ \\
\hline 33. & $\begin{array}{l}\text { Invited talk: "X-Ray Diffraction-Computed Tomography (XRD-CT) Facility at NSLS-II } \\
\text { for Nuclear Materials," ANS Winter Meeting, November } 2019 .\end{array}$ & $\begin{array}{l}\text { M. Topsakal, D. } \\
\text { Sprouster, L. Ecker }\end{array}$ \\
\hline 34. & $\begin{array}{l}\text { Invited talk: "MCNP5 Validation with a High-Reactivity Experiment in the Advanced Test } \\
\text { Reactor Critical Facility," ANS Winter Meeting, November } 2019 .\end{array}$ & $\begin{array}{l}\text { J. W. Nielsen, D. W. } \\
\text { Nigg, J. Sik Yim }\end{array}$ \\
\hline 35. & $\begin{array}{l}\text { Invited talk: "Radiation Effects in } \mathrm{ThO}_{2} \text {," Materials Research Society (MRS) Fall } \\
\text { Meeting, Boston, December } 2019 .\end{array}$ & $\begin{array}{l}\text { T. Yao, V. Chauhan, M. } \\
\text { Singh, Z. Hua, M. } \\
\text { Khafizov, A. El-Azab, } \\
\text { M. Mann, T.Wiss, J. } \\
\text { Gan, D. Hurley, L. He }\end{array}$ \\
\hline 36. & $\begin{array}{l}\text { Invited talk: "Study of Pseudomorphically Transformed bcc Mg in Mg/Nb Multilayer } \\
\text { Nanocomposite under Extreme Conditions," } 2019 \text { MRS Fall Meeting, Boston, } \\
\text { Massachusetts, December } 2019 .\end{array}$ & $\begin{array}{l}\text { M. Jain, M. Knezevic, N. } \\
\text { Velisavljevic, N. Mara, I. } \\
\text { Beyerlein, J. Michler, S. } \\
\text { Pathak }\end{array}$ \\
\hline 37. & $\begin{array}{l}\text { Invited talk: "Development, manufacturing and characterization of nanostructured materials } \\
\text { for structural applications in extreme environments," Department of Materials Science and } \\
\text { Engineering, University of California, Los Angles, January 24, } 2020 .\end{array}$ & H. Wen \\
\hline 38. & $\begin{array}{l}\text { Invited talk: "High-Entropy Carbide Ceramics for Extreme Environments in Nuclear } \\
\text { Energy Applications," } 44^{\text {th }} \text { International Conference and Exposition on Advanced Ceramics } \\
\text { and Composites (ICACC 2020), Daytona Beach, Florida, January } 2020 .\end{array}$ & B. Cui \\
\hline 39. & $\begin{array}{l}\text { Invited talk: "Radiation Effects on Phonon Transport in } \mathrm{UO}_{2} \text { and } \mathrm{ThO}_{2}, " \text { The Minerals, } \\
\text { Metals and Materials Society (TMS) Annual Meeting and Exhibition, San Diego, Feb } \\
2020 .\end{array}$ & $\begin{array}{l}\text { T. Yao, V. Chauhan, M. } \\
\text { Singh, A. Khanolkar, Z. } \\
\text { Hua, M. Khafizov, M. } \\
\text { Mann, T. Wiss, A. El- } \\
\text { Azab, J. Gan, D. Hurley, } \\
\text { L. He }\end{array}$ \\
\hline 40. & $\begin{array}{l}\text { Invited talk: "Investigation of High Burnup Ceramic Fuel Microstructure at Idaho National } \\
\text { Laboratory," TMS Annual Meeting and Exhibition, San Diego, February } 2020 .\end{array}$ & $\begin{array}{l}\text { F. Cappia, G. Beausoleil, } \\
\text { II, A. Winston, D. } \\
\text { Murry, B. Miller, L. He, } \\
\text { F. Teng }\end{array}$ \\
\hline 41. & $\begin{array}{l}\text { Invited talk: "Investigation of the Mechanism Behind Proton Irradiation Decelerated } \\
\text { Corrosion in Molten Fluorides," TMS 2020, San Diego, February } 2020 .\end{array}$ & $\begin{array}{l}\text { W. Zhou, Y. Yang, L. } \\
\text { He, A. Minor, M. Short }\end{array}$ \\
\hline 42. & $\begin{array}{l}\text { Invited talk: "Temperature Shift Evaluation for G-phase Clustering in Ferriticmartensitic } \\
\text { Alloys," TMS 2020, San Diego, February } 2020 .\end{array}$ & M. Swenson, S. Adisa \\
\hline 43. & $\begin{array}{l}\text { Invited talk: "Irradiation Damage Behavior in Novel High-Entropy Carbide Ceramics," } \\
\text { TMS } 2020 \text { 150th Annual Meeting, San Diego, California, February } 2020 .\end{array}$ & B. Cui \\
\hline
\end{tabular}




\begin{tabular}{|c|c|c|}
\hline 44. & $\begin{array}{l}\text { Invited talk: "Mechanical Properties of Ion Irradiated and Helium Implanted HT9 } \\
\text { Micropillars," TMS 2020, San Diego, February } 2020 .\end{array}$ & $\begin{array}{l}\text { R. Schoell, C. Zheng, K. } \\
\text { Hattar, D. Kaoumi }\end{array}$ \\
\hline 45. & $\begin{array}{l}\text { Invited talk: "Metallic Fast Reactor Separate Effect Studies for fuel safety," International } \\
\text { Youth Nuclear Congress, Sydney, March } 2020 .\end{array}$ & F. Di Lemma \\
\hline 46. & $\begin{array}{l}\text { Invited lecture: "Advanced Characterization of Oxide Fuels," Materials Science and } \\
\text { Engineering Department Seminar, University of Utah, March } 2020 .\end{array}$ & L. He \\
\hline 47. & $\begin{array}{l}\text { Invited talk: "The Effect of Coordination Numbers in Molten Salt Thermodynamic } \\
\text { Models," ANS Annual Meeting, June } 2020 .\end{array}$ & $\begin{array}{l}\text { M. S. Christian, J. C. } \\
\text { Ard, T. M. Besmann }\end{array}$ \\
\hline 48. & $\begin{array}{l}\text { Invited talk: "Sound Propagation Characteristic of Phononic Crystals Pipeline with Periodic } \\
\text { Vibration Isolation Mass," ANS Annual Meeting, June } 2020 .\end{array}$ & $\begin{array}{l}\text { Q. Zeng, D. Wang, F. } \\
\text { Zang, Y. Zhang, X. Jiang }\end{array}$ \\
\hline 49. & $\begin{array}{l}\text { Invited talk: "NSUF RAD-AFM: Nanoscale Material Property Measurements of } \\
\text { Radioactive Materials," ANS Annual Meeting, June } 2020 .\end{array}$ & $\begin{array}{l}\text { S. Riechers, A. Casella, } \\
\text { D. Senor, P. Ramuhalli }\end{array}$ \\
\hline 50. & $\begin{array}{l}\text { Invited talk: "Computational Analysis of Rhenium (I) Complex," ANS Annual Meeting, } \\
\text { June } 2020 .\end{array}$ & A. McKee, M. Tadesse \\
\hline 51. & $\begin{array}{l}\text { Invited talk: "Development of Yttrium Hydride Moderator for the Transformational } \\
\text { Challenge Reactor," ANS Annual Meeting, June } 2020 .\end{array}$ & $\begin{array}{l}\text { X. Hu, C. Silva, K. A. } \\
\text { Terrani }\end{array}$ \\
\hline 52. & $\begin{array}{l}\text { Invited talk: "Rapidly Screening Materials for Void Swelling Resistance with Indirect } \\
\text { Photoacoustic Measurements," ANS Annual Meeting, June } 2020 .\end{array}$ & $\begin{array}{l}\text { N. Almousa, B. Dacus, } \\
\text { K. B. Woller, C. Jang, } \\
\text { M. P. Short }\end{array}$ \\
\hline 53. & $\begin{array}{l}\text { Invited talk: "TEM characterization of the microstructure of irradiated U-Pu-Zr fuels," } \\
\text { Microscopy and Microanalysis 2020, Milwaukee, August } 2020 .\end{array}$ & $\begin{array}{l}\text { A. Aitkaliyeva, T. Rahn, } \\
\text { L. Capriotti, B. D. } \\
\text { Miller, J. Harp }\end{array}$ \\
\hline 54. & $\begin{array}{l}\text { Invited seminar: Department of Materials Sciences and Nanoengineering, Rice University, } \\
\text { September } 30,2020 \text {. }\end{array}$ & J. Li \\
\hline 55. & Invited talk: "Careers in radio/nuclear chemistry," Hampton University, September 2020. & B. Heidrich \\
\hline 56. & $\begin{array}{l}\text { Invited lecture: "Investigating Solid-Liquid Interfaces and Defect Chemistry in } \\
\text { Electrochemical Energy Systems," Department of Chemistry Seminar Series, Binghamton } \\
\text { University, September } 2020 .\end{array}$ & F. Lin \\
\hline 57. & $\begin{array}{l}\text { Invited talk: "Designing Accelerated Irradiations with Light or Heavy Ions," Accelerated } \\
\text { Irradiation for Reactor Structural Virtual Meeting, INL, September } 2020 .\end{array}$ & S. M. Pimblott \\
\hline 58. & $\begin{array}{l}\text { Contributed talk: "The FaMUS Methodology for Quantify Materials Understanding and its } \\
\text { Application to the NSUF Research Portfolio," TMS } 2020 \text { Annual Meeting \& Exhibition, } \\
\text { San Diego, Feb } 2020 .\end{array}$ & S. M. Pimblott \\
\hline 59. & $\begin{array}{l}\text { Session Organizer and Chair: Nuclear Science User Facilities Sessions I and II, ANS } \\
\text { Winter Meeting, November } 2019 .\end{array}$ & J. R. Kennedy \\
\hline 60. & $\begin{array}{l}\text { Session Chair: Nuclear Science User Facilities/Molten Salt Reactor Session and } \\
\text { Accelerated Materials Discovery Session, ANS Annual Meeting, June } 2020 .\end{array}$ & J. R. Kennedy \\
\hline 61. & $\begin{array}{l}\text { Session Chair: In-Reactor Capsule Designs, INL accelerated Irradiations for Reactor } \\
\text { Structural Materials Workshop, September } 2020 .\end{array}$ & B. Heidrich \\
\hline 62. & $\begin{array}{l}\text { Program Office Publication: S.M. Pimblott \& J.R. Kennedy, "Progress in Critically } \\
\text { Assessing the NSUF Research Portfolio," Trans. Am. Nucl. Soc. 2019, 121, 634-635. }\end{array}$ & $\begin{array}{l}\text { S. M. Pimblott, J. R. } \\
\text { Kennedy }\end{array}$ \\
\hline \multicolumn{3}{|c|}{ FY 2019} \\
\hline 1. & $\begin{array}{l}\text { G. R. Odette was elected as a fellow of American Association for the Advancement of } \\
\text { Science (AAAS) } 2019 .\end{array}$ & G. R. Odette \\
\hline 2. & U.S. Department of Energy Office of Science Early Career Award, 2019. & J. P. Wharry \\
\hline 3. & $\begin{array}{l}\text { General Scientific Infrastructure (GSI) award to University of Nevada-Reno enabled the } \\
2019 \text { DARPA Young Faculty Award, "Additive Manufacturing of Functional Hierarchical } \\
\text { Shape Memory Alloy Structures," 2019-2022. }\end{array}$ & S. Pathak \\
\hline 4. & $\begin{array}{l}\text { Best poster within the ATF topic track and honorable mentions for best overall poster, } \\
\text { "Mechanical and Hermetic Performance of SiC-SiC Joints in Representative Cladding } \\
\text { Geometries," NuMat2018: The Nuclear Materials Conference, October 14-18, 2018, } \\
\text { Seattle, WA. }\end{array}$ & C. Deck \\
\hline 5. & TMS Best Paper Award - Graduate Division, $2^{\text {nd }}$ place, July 2019. & K. Mao \\
\hline
\end{tabular}




\begin{tabular}{|c|c|c|}
\hline 6. & $\begin{array}{l}\text { Member of the Scientific Committee for the European Materials Research Society (E- } \\
\text { MRS) Nuclear Materials Symposium, Nice, France, May } 2019 .\end{array}$ & J. R. Kennedy \\
\hline 7. & Member of the ANS Materials Science and Technology Division Executive Committee. & J. R. Kennedy \\
\hline 8. & PhD student thesis in Nuclear Science and Engineering, MIT, Y. Yang, December 2018. & Y. Yang \\
\hline 9. & $\begin{array}{l}\text { PhD dissertation: "Influence of irradiation and laser welding on deformation mechanisms in } \\
304 \text { austenitic stainless steels," Materials Engineering, Purdue University, May } 2019 .\end{array}$ & K. S. Mao (PhD student) \\
\hline 10 . & $\begin{array}{l}\text { PhD dissertation: "In situ TEM mechanical testing of irradiated oxide dispersion } \\
\text { strengthened alloys," Materials Engineering, Purdue University, May } 2019 .\end{array}$ & $\begin{array}{l}\text { K. H. Yano (PhD } \\
\text { student) }\end{array}$ \\
\hline 11. & $\begin{array}{l}\text { Doctor of Philosophy in Materials Science, "Investigation of thermal degradation in } \\
\text { structural alloys for nuclear power systems," Oregon State University, presented on } \\
\text { December 7, } 2018 \text {. }\end{array}$ & F. Teng \\
\hline 12. & $\begin{array}{l}\text { PhD dissertation: "Development and characterization of nanostructured steels and high- } \\
\text { entropy alloys for nuclear applications," Nuclear Engineering Department, Missouri } \\
\text { University of Science and Technology, August } 2019 .\end{array}$ & $\begin{array}{l}\text { A. Hoffman }(\mathrm{PhD} \\
\text { student) }\end{array}$ \\
\hline 13. & $\begin{array}{l}\text { PhD dissertation: "The radial evolution of microstructure and fission products in fast } \\
\text { reactor mixed oxide fuels," Department of Materials Science and Engineering, University } \\
\text { of Florida, August 9,2019. }\end{array}$ & R. Parrish (PhD student) \\
\hline 14. & Organized an NSUF symposium at the April 2019 ANS Student Meeting. & $\begin{array}{l}\text { S. M. Pimblott, B. } \\
\text { Heidrich }\end{array}$ \\
\hline 15. & $\begin{array}{l}\text { Organized and chaired two session for "Nuclear Science User Facilities-II" at the } 2019 \\
\text { ANS Annual Meeting, Minneapolis, MN, June 2019. }\end{array}$ & J. R. Kennedy \\
\hline 16. & $\begin{array}{l}\text { Organized the University Research Reactor Fitness Workshop at the CAES, Idaho Falls, } \\
\text { ID, July } 16-17,2019 .\end{array}$ & B. Heidrich \\
\hline 17. & $\begin{array}{l}\text { Organized and chaired session at the 19th International Conference on Environmental } \\
\text { Degradation of Materials in Nuclear Power Systems-Water Reactors, August 2019, } \\
\text { Boston, MA. }\end{array}$ & S. M. Pimblott \\
\hline 18. & $\begin{array}{l}\text { Organized session for "University Research Reactor Fitness Workshop Panel" at the } \\
\text { National Organization of Research, Test, and Training Reactors meeting, Idaho Falls, ID, } \\
\text { September } 2019 .\end{array}$ & $\begin{array}{l}\text { B. Heidrich, B. Meffert, } \\
\text { M. Lund, J. Geuther }\end{array}$ \\
\hline 19. & $\begin{array}{l}\text { Invited talk: "Microscopy and microanalysis of nuclear fuels," presented at } 2018 \text { Materials } \\
\text { Science \& Technology meeting, Columbus, OH, October 14-18, } 2018 .\end{array}$ & A. Aitkaliyeva \\
\hline 20 . & $\begin{array}{l}\text { Invited talk: "Physically Based Low Flux-High Fluence RPV Steel Embrittlement Models," } \\
\text { Materials Science and Technology presented at } 2018 \text { Materials Science \& Technology } \\
\text { meeting, Columbus, OH, October 14-18, } 2018 .\end{array}$ & $\begin{array}{l}\text { G.R. Odette, T. } \\
\text { Yamamoto, P. Wells, N. } \\
\text { Almirall, R. Nanstad }\end{array}$ \\
\hline 21. & $\begin{array}{l}\text { Invited talk: "The US Nuclear Science User Facilities," presented to the Japan Ministry of } \\
\text { Education, Culture, Sports, Science and Technology (MEXT), November 12, } 2018 .\end{array}$ & D. Ogden \\
\hline 22. & $\begin{array}{l}\text { Invited Graduate Seminar: "Neutron Irradiation Challenges and Opportunities in Nuclear } \\
\text { Energy Research and Development," presented to the Department of Nuclear Engineering } \\
\text { Graduate Seminar, University of Michigan, Ann Arbor, MI, November 30, 2018; presented } \\
\text { to the Department of Physics Graduate Seminar, University of Idaho, Moscow, ID, April 8, } \\
\text { 2019; and presented to the Department of Nuclear Engineering Graduate Seminar, } \\
\text { Pennsylvania State University, University Park, PA, July 22, } 2019 .\end{array}$ & B. Heidrich \\
\hline 23. & $\begin{array}{l}\text { Invited talk: "DOE Nuclear Science User Facility Program" presented at the Molten Salt } \\
\text { Reactors Technology Working Group Meeting," Nuclear Energy Institute, Washington } \\
\text { D.C., December } 2018 \text {. }\end{array}$ & S. M. Pimblott \\
\hline 24. & $\begin{array}{l}\text { Contributed talk at "Radiolytic Damage at Carbide-Water Interfaces, Advanced Accident } \\
\text { and Radiation Tolerant Materials," Cambridge, UK, February } 2019 .\end{array}$ & S. M. Pimblott \\
\hline 25. & $\begin{array}{l}\text { Invited lecture: "Recent progress in testing and qualification of PM-HIP alloys for nuclear } \\
\text { applications," TMS Annual Meeting, San Antonio TX, March } 2019 .\end{array}$ & $\begin{array}{l}\text { J. P. Wharry, M. J. Pavel, } \\
\text { Z. T. Kroll, E. Bautista, } \\
\text { A. Bullens, D. P. } \\
\text { Guillen, L. A. Giannuzzi, } \\
\text { E. Getto, D. Pagan, P. D. } \\
\text { Freyer, D. W. Gandy }\end{array}$ \\
\hline
\end{tabular}




\begin{tabular}{|c|c|c|}
\hline 26. & $\begin{array}{l}\text { Invited talk: "Effect of Friction Stir Welding on Microstructure Evolution on -Ion } \\
\text { Irradiated MA956," at the Materials Society Annual Meeting \& Exhibition 2019, San } \\
\text { Antonio, Texas, March 10-14,2019. }\end{array}$ & $\begin{array}{l}\text { E. Getto, B. Tobie, S. } \\
\text { Briggs, K. Hattar, B. } \\
\text { Baker }\end{array}$ \\
\hline 27. & $\begin{array}{l}\text { Keynote lecture: "Neutron Irradiation Effects on The Microstructure of Nuclear Graphite," } \\
\text { TMS 2019, San Antonio, TX, March 10-14, } 2019 .\end{array}$ & $\begin{array}{l}\text { J. Arregui-Mena, P. } \\
\text { Edmondson, R. Worth, } \\
\text { C. Contescu, T. Burchell, } \\
\text { D. Cullen, Y. Kato }\end{array}$ \\
\hline 28. & $\begin{array}{l}\text { Invited talk: "Irradiation Effects on Precipitation in Multiconstituent Steels," TMS 2019, } \\
\text { San Antonio, TX, March 11-15, } 2019 .\end{array}$ & $\begin{array}{l}\text { G.R. Odette, N. Almirall, } \\
\text { P. Wells, T. Yamamoto, } \\
\text { E. Marquis, S. Shu, D. } \\
\text { Morgan, J.H. Ke, H. Ke }\end{array}$ \\
\hline 29. & $\begin{array}{l}\text { Invited talk: "A New RPV Steel Low Flux-High Fluence Embrittlement Model for the US } \\
\text { Surveillance Database,” TMS 2019, San Antonio, TX, March 11-15, } 2019 .\end{array}$ & $\begin{array}{l}\text { G.R. Odette, T. } \\
\text { Yamamoto, P. Wells, N. } \\
\text { Almirall }\end{array}$ \\
\hline 30. & $\begin{array}{l}\text { Invited talk: "In situ irradiation and heating of synthetic SiC and implications for the } \\
\text { origins of C-rich circumstellar materials," at the 50th Lunar and Planetary Science } \\
\text { Conference, abstract \#2127, Houston, TX, March 21, } 2019 .\end{array}$ & $\begin{array}{l}\text { T.J. Zega, J. Bernal, J.Y. } \\
\text { Howe, P. Haenecour, S. } \\
\text { Amari, L.M. Ziurys }\end{array}$ \\
\hline 31. & $\begin{array}{l}\text { Invited lecture: "Irradiation Damage Behavior in Novel High-Entropy Carbide Ceramic," } \\
2019 \text { ANS Annual Meeting, Minneapolis, Minnesota, June 10, } 2019 .\end{array}$ & C. Bai \\
\hline 32. & $\begin{array}{l}\text { Contributed talk "Development of the FaMUS Methodology for Quantifying Materials } \\
\text { Understanding and its Application to the NSUF," ANS Annual Meeting, Minneapolis, MN, } \\
\text { USA, June 2019. }\end{array}$ & S. M. Pimblott \\
\hline 33. & $\begin{array}{l}\text { Invited panelist: "Challenges Associated with Material Transport into and Waste Removal } \\
\text { from Hot Cell R\&D Facilities Worldwide," ANS Annual Meeting, Minneapolis, MN, June } \\
2019 \text { (declined due to schedule conflict). }\end{array}$ & J. R. Kennedy \\
\hline 34. & $\begin{array}{l}\text { Invited talk: "The US Nuclear Science User Facilities," presented to the Czech Republic } \\
\text { Delegation, June 12, } 2019 .\end{array}$ & D. Ogden \\
\hline 35. & $\begin{array}{l}\text { Invited lecture: “The Nuclear Science User Facilities (NSUF),” MeV School, ORNL, } \\
\text { Knoxville, TN, July } 2019 .\end{array}$ & S. M. Pimblott \\
\hline 36. & $\begin{array}{l}\text { Invited lecture: "Role of irradiation and weld-induced post-irradiation annealing on } \\
\text { deformation mechanisms in 304L stainless steel," 10th Pacific Rim International } \\
\text { Conference on Advanced Materials and Processing (PRICM-10), Xi'an China, August } \\
2019 \text {. }\end{array}$ & $\begin{array}{l}\text { J. P. Wharry, K. S. Mao, } \\
\text { C. Sun, P. D. Freyer, F. } \\
\text { A. Garner }\end{array}$ \\
\hline 37. & $\begin{array}{l}\text { Invited talk: "Putting stars in the gap: In situ irradiation and heating of synthetic } \mathrm{SiC} \text { and } \\
\text { Implications for the origins of C-rich circumstellar materials. Microscopy and } \\
\text { Microanalysis 25," abstract \#2488, Portland, OR, August 8, } 2019 .\end{array}$ & $\begin{array}{l}\text { T.J. Zega, J. Bernal, J.Y. } \\
\text { Howe, P. Haenecour, S. } \\
\text { Amari, and L.M. Ziurys }\end{array}$ \\
\hline 38. & $\begin{array}{l}\text { Invited talk: "The US Nuclear Science User Facilities," presented to the New Reactor } \\
\text { Leadership Delegation, MIT, Boston, MA, September 12, } 2019 .\end{array}$ & D. Ogden \\
\hline 39. & $\begin{array}{l}\text { Invited talk: "Radiation Effects on Heterogeneous Systems," Miller Conference, Cumbria, } \\
\text { UK, September } 2019 .\end{array}$ & S. M. Pimblott \\
\hline 40. & $\begin{array}{l}\text { Keynote lecture: “Assessment of Neutron Damage in Irradiated Graphite Using Gas } \\
\text { Adsorption Methods,” INGSM (International Nuclear Graphite Specialists Meeting), } \\
\text { Bruges, Belgium, September 16-19, } 2019 .\end{array}$ & $\begin{array}{l}\text { C. Contescu, J. Spicer, } \\
\text { N. Gallego, A. Campbell, } \\
\text { J. Arregui-Mena, T. } \\
\text { Burchell }\end{array}$ \\
\hline 41. & $\begin{array}{l}\text { Invited talk, "Nuclear Science User Facilities (NSUF)," at the 7th Nuclear Universities } \\
\text { Consortium for Learning, Engagement and Research Academics Discussion Meeting } \\
\text { (NADM), Bangor University, September 2019, Bangor, UK. }\end{array}$ & J. R. Kennedy \\
\hline 42. & $\begin{array}{l}\text { Keynote lecture: "A Multi-Technique Image Library of Graphite Microstructures," INGSM } \\
\text { (International Nuclear Graphite Specialists Meeting), Bruges, Belgium, Sept 16-19, } 2019 .\end{array}$ & $\begin{array}{l}\text { J. Arregui-Mena, C. } \\
\text { Contescu, D. Griffiths, } \\
\text { R. Worthm L. Margetts, } \\
\text { P. Mummery, A. } \\
\text { Campbell, N. } \\
\text { Gallego, E. Cakmak, C. } \\
\text { Hayes, T. Burchell, Y. } \\
\text { Kato, P. Edmondson }\end{array}$ \\
\hline
\end{tabular}




\begin{tabular}{|c|c|c|}
\hline 43. & $\begin{array}{l}\text { Keynote lecture: "Ultra-High Temperature Neutron Irradiation Effects on Graphite } \\
\text { Microstructure," INGSM (International Nuclear Graphite Specialists Meeting), Bruges, } \\
\text { Belgium, Sept 16-19, 2019. }\end{array}$ & $\begin{array}{l}\text { A. Campbell, E. } \\
\text { Cakmak, C. Contescu, N. } \\
\text { Gallego, T. Burchell }\end{array}$ \\
\hline 44. & $\begin{array}{l}\text { Invited panel member for the UK Engineering and Physical Sciences Research Council } \\
\text { (EPSRC) National Nuclear User Facility (NNUF) Phase } 2 \text { Call Review and Prioritization } \\
\text { Panel. The panel was to make recommendations on } £ 81.5 \mathrm{M}(>\$ 100 \mathrm{M}) \text { worth of } \\
\text { infrastructure requests from UK nuclear researchers. }\end{array}$ & J. R. Kennedy \\
\hline 45. & $\begin{array}{l}\text { Invited lecture: Berkley Colloquium lecture at the University of California (declined due to } \\
\text { schedule conflict). }\end{array}$ & J. R. Kennedy \\
\hline 46. & $\begin{array}{l}\text { Session chair for "In-Pile Instrumentation Development at INL" and "Advanced } \\
\text { Instrumentation" at the } 11^{\text {th }} \text { Nuclear Plant Instrumentation, Control and Human-Machine } \\
\text { Interface Technologies ANS conference, Orlando, FL, February } 2019 \text {. }\end{array}$ & B. Heidrich \\
\hline 47. & $\begin{array}{l}\text { Chaired Isotopes and Radiation Division General Session and three Irradiation Experiments } \\
\text { Sessions at the } 2019 \text { Annual Meeting of the ANS, Minneapolis, MN June 9-13, } 2019 .\end{array}$ & B. Heidrich \\
\hline 48. & $\begin{array}{l}\text { Chaired "Accident Tolerant Fuels - I" session at the } 2019 \text { ANS Annual Meeting, } \\
\text { Minneapolis, MN, June } 2019 .\end{array}$ & J. R. Kennedy \\
\hline 49. & $\begin{array}{l}\text { The NSUF is lead for the Enabling Technologies Working Group of the US DOE - UK } \\
\text { BEIS Nuclear Energy Research and Development Cooperative Action Plan. }\end{array}$ & J. R. Kennedy \\
\hline
\end{tabular}

\section{Conclusions:}

The prominence/positive exposure for the NSUF and the user community increased significantly in FY 2020, exceeding the goal of 5\%.

Of notable interest, there were eight Ph.D. dissertations/thesis granted in FY 2020 that were attributed to NSUF-awarded projects.

The prominence/positive exposure for the NSUF has continued to increase as a result of both the quantity and quality of the research, publications, and awarded proposals.

\section{NSUF EXPANSION AND DIVERSIFICATION OF NSUF USER COMMUNITY}

1. Metric Objective: Expand and diversify the NSUF user community.

2. Performance Metric: Number of proposals received and awarded gauged against available funding, project type, number of new PIs, institutions, and geographic distribution.

3. Performance Goal: Analyze data to identify and act upon trends, deficiencies, and exceptionalities.

To show how the NSUF is performing, Figure 5 and Table 9 provide a historical overview of the number of RTE proposals, RTE awards, CINR pre-applications, and CINR awards. In addition, a historical plot of new budget authority (BA) is provided as a reference point to show available NSUF program funding. For this plot, new BA is calculated by taking the full NSUF appropriation and subtracting congressionally directed activities and HQ external contributions. 


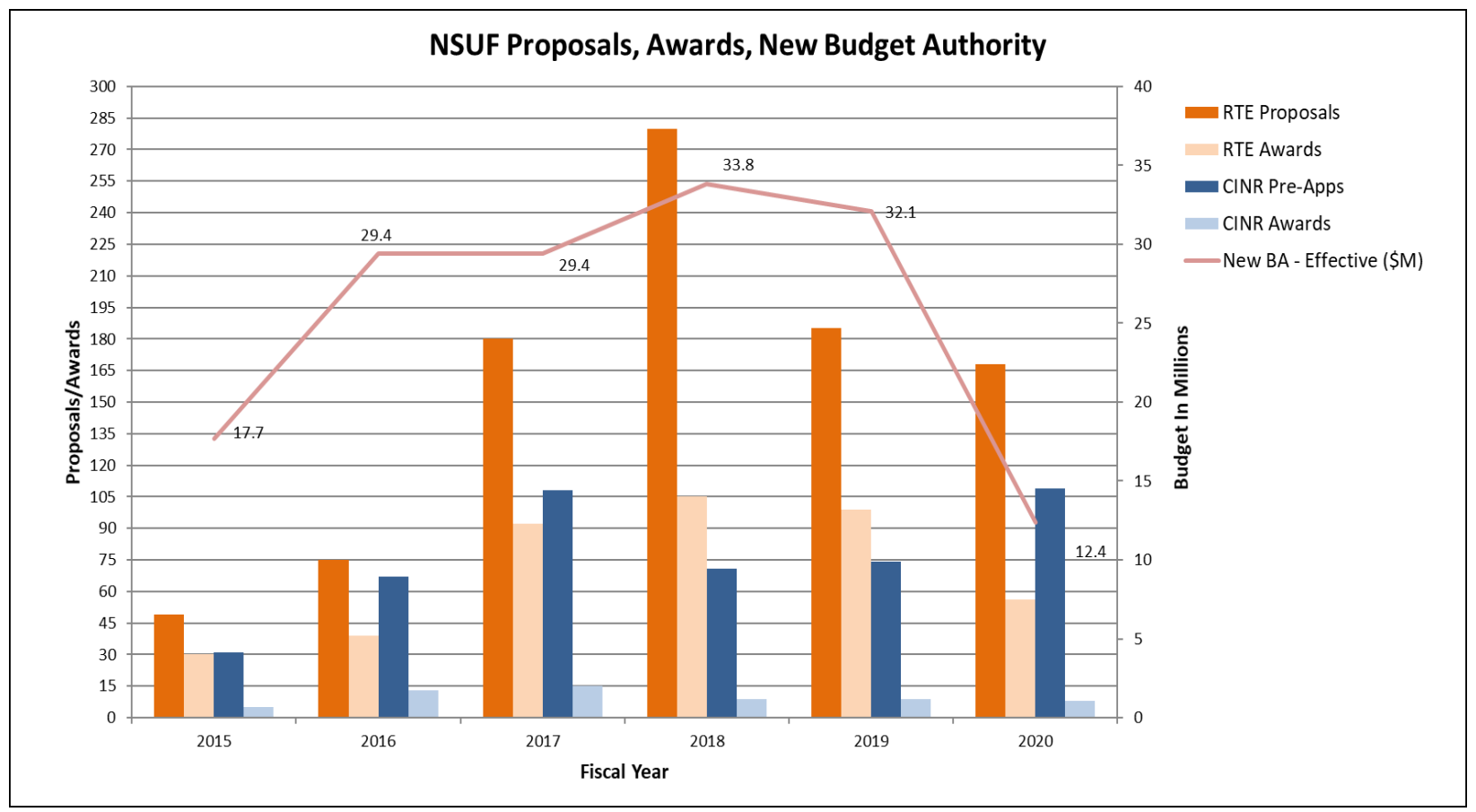

Figure 5. NSUF proposals, awards, and new BA.

Table 9. NSUF proposals, awards, and new BA (\$M).

\begin{tabular}{|l|c|c|c|c|c|c|}
\hline & $\mathbf{2 0 1 5}$ & $\mathbf{2 0 1 6}$ & $\mathbf{2 0 1 7}$ & $\mathbf{2 0 1 8}$ & $\mathbf{2 0 1 9}$ & $\mathbf{2 0 2 0}$ \\
\hline RTE Proposals & 49 & 75 & 180 & 280 & 185 & 168 \\
\hline RTE Awards & 30 & 39 & 92 & 105 & 99 & 56 \\
\hline CINR Pre-Apps & 31 & 67 & 108 & 71 & 74 & 109 \\
\hline CINR Awards & 5 & 13 & 15 & 9 & 9 & 8 \\
\hline New BA Effective (\$M) & 17.7 & 29.4 & 29.4 & 33.8 & 32.1 & 12.4 \\
\hline
\end{tabular}

To help illustrate expansion and diversification, Figure 6 and Table 10 provide an overview of the number of combined CINR and RTE awards by fiscal year made to international, national laboratory, industrial, and university institutions. A plot of the total number of PIs and new PIs per year is also provided. 


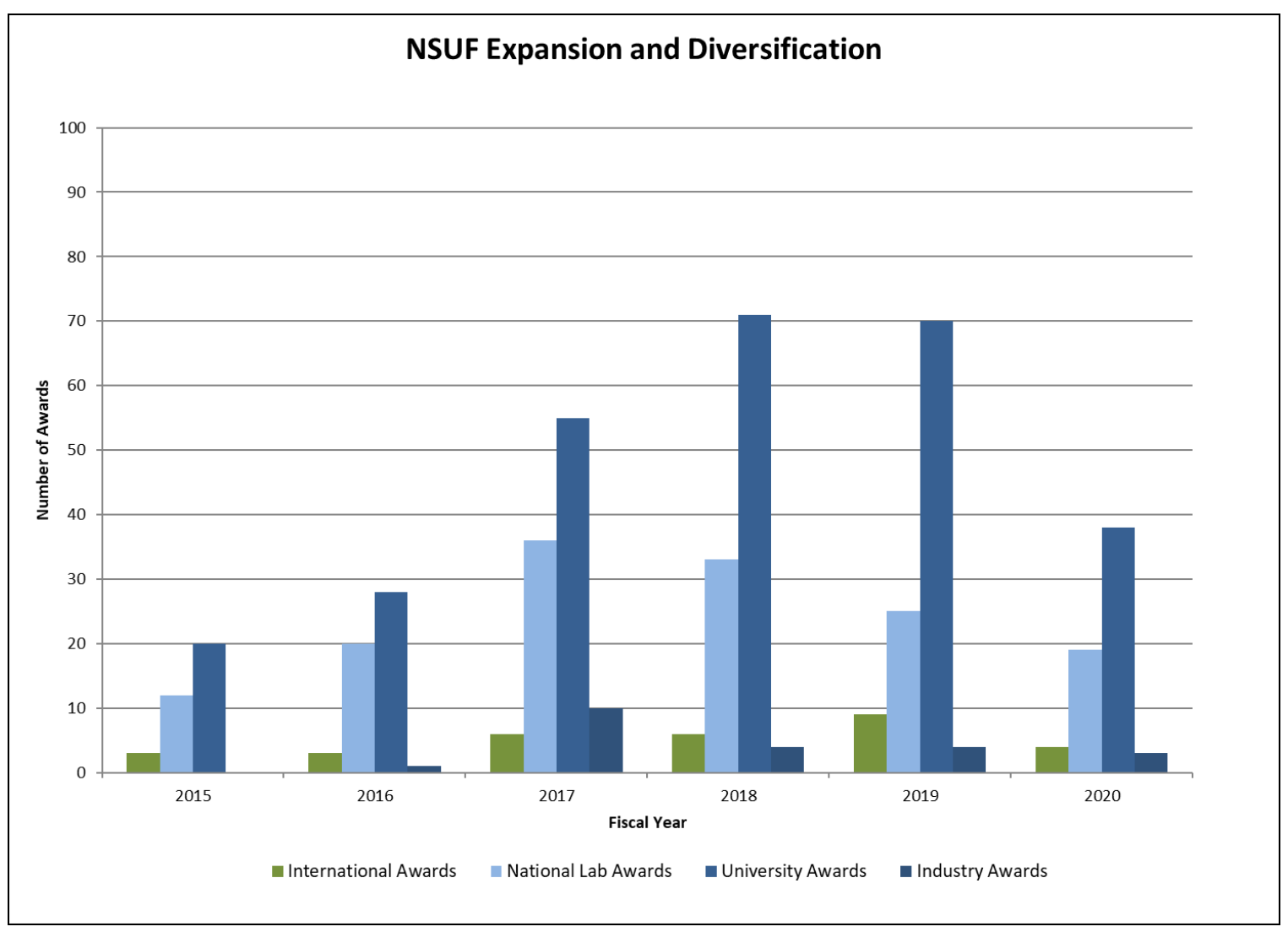

Figure 6. NSUF expansion and diversification.

Table 10. NSUF expansion and diversification.

\begin{tabular}{|l|c|c|c|c|c|c|}
\hline & FY 2015 & FY 2016 & FY 2017 & FY 2018 & FY 2019 & FY 2020 \\
\hline International Awards & 3 & 3 & 6 & 6 & 9 & 4 \\
\hline National Lab Awards & 12 & 20 & 36 & 33 & 25 & 19 \\
\hline University Awards & 20 & 28 & 55 & 71 & 70 & 38 \\
\hline Industry Awards & 0 & 1 & 10 & 4 & 4 & 3 \\
\hline & FY 2015 & FY 2016 & FY 2017 & FY 2018 & FY 2019 & FY 2020 \\
\hline Total PIs Per Year & 24 & 42 & 78 & 92 & 95 & 64 \\
\hline \% New PIs Per Year & $63 \%$ & $74 \%$ & $71 \%$ & $53 \%$ & $58 \%$ & $41 \%$ \\
\hline \% Female PIs Per Year & $33 \%$ & $24 \%$ & $17 \%$ & $16 \%$ & $22 \%$ & $19 \%$ \\
\hline
\end{tabular}

In FY 2020, the NSUF had a significant decrease in budget for new awards which resulted in fewer awards being made. This had a negative impact on the NSUF's expansion and diversification efforts. The number of projects awarded internationally decreased from nine in FY 2019 to four in FY 2020. The overall number of awards to industry decreased by one. However, it is observed that industry RTE awards increased from zero in FY 2019 to two in FY 2020.

There was a decrease in the number of new PIs from 55 in FY 2019 to 26 in FY 2020. This decrease can also be attributed to the decrease of the NSUF award budget. Regarding diversification, there was a total of 64 NSUF PIs awarded in FY 2020. Fifty-two of these were male and 12 were female. The 12 awarded female PIs represent $19 \%$ of the awards granted which is similar to last year's 
percentage. Further analysis of the FY 2020 RTE awards to female PIs helps illustrate another positive aspect of NSUF diversification efforts. Out of the 168 RTE proposals submitted by PIs, female PIs had a $41 \%$ success rate (13 of 32 ) and males PIs had a $31 \%$ success rate (42 of 136) of proposals submitted to RTE calls.

Based on a readily available list of minority-serving institutions that was generated from CY 2020 data from the U.S. Department of Education (https://cmsi.gse.rutgers.edu/sites/default/files/MSI\%20List\%202021.pdf), the NSUF awarded three proposals to PIs from minority-serving institutions. Two awards were made to PIs from the University of New Mexico and one award was made to a PI from the University of California- Irvine.

In FY 2020, the NSUF experienced a 9\% decrease in the number of RTE proposals submitted and a large increase (47\%) in the number of CINR pre-applications submitted. The decrease in RTE proposals was attributed to only having two RTE calls rather than three. The NSUF only had two RTE calls due to budget limitations. Although the overall RTE applications were down for FY 2020 due to having only two RTE calls, FY 2020 RTE application numbers (168) were approaching the number of RTE applications (185) for FY 2019, which had three calls. This demonstrates a strong interest/demand for RTE access to NSUF facilities. User interest also continues to be high as demonstrated by the $47 \%$ increase from FY 2019 to FY 2020 in the number of CINR applications.

\section{Conclusions:}

The NSUF continues to maintain a high level of user demand. The steady stream of successful new PIs coupled with a steady stream of returning PIs demonstrates the value that the NSUF has to researchers at all levels of experience. Budget constraints limited further expansion and diversification by reducing the number of calls and awards available to PIs.

\section{CONCLUSIONS}

In conclusion, the NSUF exceeded the performance goals for four of the five metrics.

Significant findings from the reported data include:

- Demand for facility access through the NSUF remains strong.

- The number of publications per year continues to increase, although this year's data may indicate that the number could start leveling off.

- The scientific quality of NSUF publications is demonstrated by a growing number of citations to the publications.

- The NSUF requires a budget of at least $\$ 50 \mathrm{M}$ in order to maintain a high level of performance while supporting High Performance Computing and other appropriation earmarks.

The metrics reported here were first established in FY 2014 and have provided important data for managing the NSUF program as well as setting goals and directions that enhance the national organization. Taken together, the interplay and interdependence between available budget, number and quality of proposals received, expansion and diversification of capabilities and the user community, quality and impact of the research performed, and the prominence and positive exposure of the NSUF and its users can be clearly seen through the analysis of these metrics. The NSUF will continue to analyze metrics to help improve its performance in fulfilling the mission of DOE-NE and addressing the challenges confronting the nuclear research community. 